ADVANCES IN SPANISH PHYSICAL

OCEANOGRAPHY

M. Espino, J. Font, J.L. Pelegrí,

A. Sánchez-Arcilla (eds.)
Scientia Marina 76S1

September 2012, 79-94, Barcelona (Spain)

ISSN: 0214-8358

doi: $10.3989 /$ scimar.03608.18D

\title{
A Lagrangian study tracing water parcel origins in the Canary Upwelling System
}

\author{
EVAN MASON $^{1}$, FRANCOIS COLAS ${ }^{2,3}$ and JOSEP L. PELEGRÍ ${ }^{1}$ \\ ${ }^{1}$ Departament d'Oceanografía Física, Institut de Ciències del Mar, CSIC, Passeig Marítim de la Barceloneta 37-49, \\ 08003 Barcelona, Spain. E-mail: emason@icm.csic.es \\ ${ }^{2}$ Laboratoire d'Océanographie et du Climat: Expérimentation et Approches Numériques, LOCEAN/IRD/IPSL/UPMC, \\ Paris, France. \\ ${ }^{3}$ Institute of Geophysics and Planetary Physics, University of California Los Angeles, Los Angeles, California, USA.
}

SUMMARY: The regional ocean circulation within the Canary Upwelling System between $31^{\circ} \mathrm{N}$ and $35^{\circ} \mathrm{N}$ is studied using numerical tools. Seasonal mean and near-instantaneous velocity fields from a previously-generated climatological Regional Ocean Modelling System (ROMS) solution of the Canary Basin are used to force a series of offline Lagrangian particletracking experiments. The primary objective is to identify the pathways through which water parcels arrive at the upwelling region north of Cape Ghir. Examining year-long pathways, the Azores Current contributes over $80 \%$ of particles annually, of which a large proportion arrive directly from offshore (from the northwest), while others travel along the shelf and slope from the Gulf of Cadiz. The remaining $~ 20 \%$ originate within the Gulf of Cadiz or come from the south, although the southern contribution is only significant in autumn and winter. When season-long pathways are considered, the alongshore contributions become increasingly important: northern contributions reach $40 \%$ in spring and summer, while southern values exceed $35 \%$ in winter. This study also shows that coastal upwelling changes both spatially and temporally. Upwelling becomes intensified near Cape Beddouza, with most upwelling occurring within $\sim 40 \mathrm{~km}$ from shore although significant values may reach as far as $120 \mathrm{~km}$ offshore north of Cape Beddouza; at these locations the offshore integrated upwelling reaches as much as 4 times the offshore Ekman transport. In the Cape Beddouza area $\left(32^{\circ} \mathrm{N}\right.$ to $\left.33^{\circ} \mathrm{N}\right)$, upwelling is negligible in February but intensifies in autumn, reaching as much as 3 times the offshore Ekman transport.

Keywords: Canary Upwelling System, Canary Current, Lagrangian model, hydrodynamic model, ROMS, seasonal variability.

RESUMEN: Estudio Lagrangiano sobre el origen de las parcelas de agua en el Sistema de Afloramiento de CANARIAS. - Se estudia la circulación oceánica regional en el Sistema de Afloramiento de Canarias entre 31 y $35^{\circ} \mathrm{N}$ mediante herramientas numéricas. Con este fin se realizan una serie de experimentos de seguimientos de partículas Lagrangianas mediante los campos de velocidad, tanto los medios estacionales como los cuasi-instantáneos, obtenidos a partir de una solución previamente generada del Sistema de Modelado Oceánico Regional (ROMS). El objetivo principal es identificar las rutas mediante las cuales las parcelas de agua llegan a la región de afloramiento al norte de Cabo Ghir. Al examinar las rutas anuales se aprecia que la Corriente de Azores contribuye con más del $80 \%$ de las partículas, una gran proporción de las cuales llega directamente desde costa afuera (desde el noroeste) mientras que otras siguen la plataforma y el talud continental desde el Golfo de Cádiz. Las restantes $\sim 20 \%$ se originan en el Golfo de Cádiz o vienen desde el sur, aunque la contribución sureña solo es significativa en otoño e invierno. Al examinar las rutas estacionales se observa que las contribuciones a lo largo de la costa se tornan más importantes: la contribución norteña alcanza el $40 \%$ en primavera y verano mientras que las partículas originadas al sur exceden un 35\% en invierno. Este estudio también muestra que el afloramiento costero cambia temporal y espacialmente. El afloramiento se intensifica cerca de Cabo Beddouza, con la mayor parte del afloramiento teniendo lugar en unos $\sim 40 \mathrm{~km}$ desde la costa, aunque se obtienen valores significativos a distancias de hasta $120 \mathrm{~km}$ fuera de costa al norte de Cabo Beddouza; en estas mismas localidades el afloramiento integrado costa afuera alcanza hasta 4 veces el transporte de Ekman perpendicular a costa. En el área de Cabo Beddouza $\left(32\right.$ a $\left.33^{\circ} \mathrm{N}\right)$, el afloramiento es despreciable en febrero pero se intensifica en otoño, alcanzando hasta 3 veces el transporte de Ekman perpendicular a costa.

Palabras clave: Sistema de Afloramiento de Canarias, Corriente de Canarias, modelo Lagrangiano, modelo hidrodinámico, ROMS, variabilidad estacional. 


\section{INTRODUCTION}

The Canary Upwelling System (CUS) situated off northwest Africa and the western Iberian Peninsula (IP) is one of the four main eastern boundary upwellings which together occupy just $0.1 \%$ of the world ocean, yet account for $30 \%$ of the world's fish catch (Durand et al. 1998; Carr and Kearns 2003, Rykaczewski and Checkley 2008, Arístegui et al. 2009). Wind-driven upwelling occurs over the full extent of the CUS (13$43^{\circ} \mathrm{N}$ ), aside from a small interruption at the Strait of Gibraltar, although its presence and intensity is governed by seasonal variations (Wooster et al. 1976, Speth and Detlefsen 1982, Nykjær and Van Camp 1994, Estrade et al. 2008, Gómez-Gesteira et al. 2008, Lathuiliére et al. 2008, Marcello et al. 2011). Between the Canary Islands and the Strait of Gibraltar, the region of interest in this study, upwelling is present all year but peaks in summer when the Azores high pressure cell occupies its most northerly position. To the south, between $20^{\circ} \mathrm{N}$ and $25^{\circ} \mathrm{N}$, the Trade winds are constant and upwelling is permanent throughout the year. At the northern limit (i.e. the western IP) the upwelling season is generally limited to late spring through early autumn, although intermittent wintertime upwelling events are also observed (e.g. Borges et al. 2003, Santos et al. 2004).

The situation of the CUS is shown in the schematic map of Figure 1. Off northwest Africa the Canary Current (CanC) flows southwards (Machín et al. 2006a, Mason et al. 2011). The current is perturbed by the Canary Island archipelago at $\sim 28^{\circ} \mathrm{N}$, generating an energetic eddy field (Arístegui et al. 1994, Piedeleu et al. 2009, Sangrà et al. 2009). The geometry of the northwest African coastline has a distinct concave shape south of Cape Ghir $\left(30.6^{\circ} \mathrm{N}\right)$, while to the north it is convex. Located in the surface layers over the shelf and slope is the equatorward-flowing Canary Upwelling Current (CanUC; Pelegrí et al. 2005a, 2006), and its associated undercurrent at depth (Barton 1989). The CanUC is thought to originate in the region just south of the Gulf of Cadiz, where several studies have shown the existence of an inflow of North Atlantic Central Water ( 1-2 Sv; NACW) from the open ocean to the coastal region (Stramma 1984, Lozier et al. 1995, Machín et al. 2006b). The conduit for this transfer is the zonal Azores Current $(\mathrm{AzC})$, which transports about $3 \mathrm{~Sv}$ into the Gulf of Cadiz region (Peliz et al. 2007, Lamas et al. 2010). The so-called Eastern Boundary Current (EBC) describes the general alongshore off-slope flow regime in the NACW layer $(\sim 0-600 \mathrm{~m})$ along the Moroccan coast and within the Lanzarote Passage (LP). This deep flow experiences an annual reversal from equatorward to poleward flow that usually occurs around November (Fraile-Nuez et al. 2010, Mason et al. 2011).

The Cape Ghir region has been implicated in the generation of westward-propagating baroclinic planetary waves that have a significant influence on the spatio-temporal variability of the CanC (Hagen 2001, Mason et al. 2011). This low-frequency

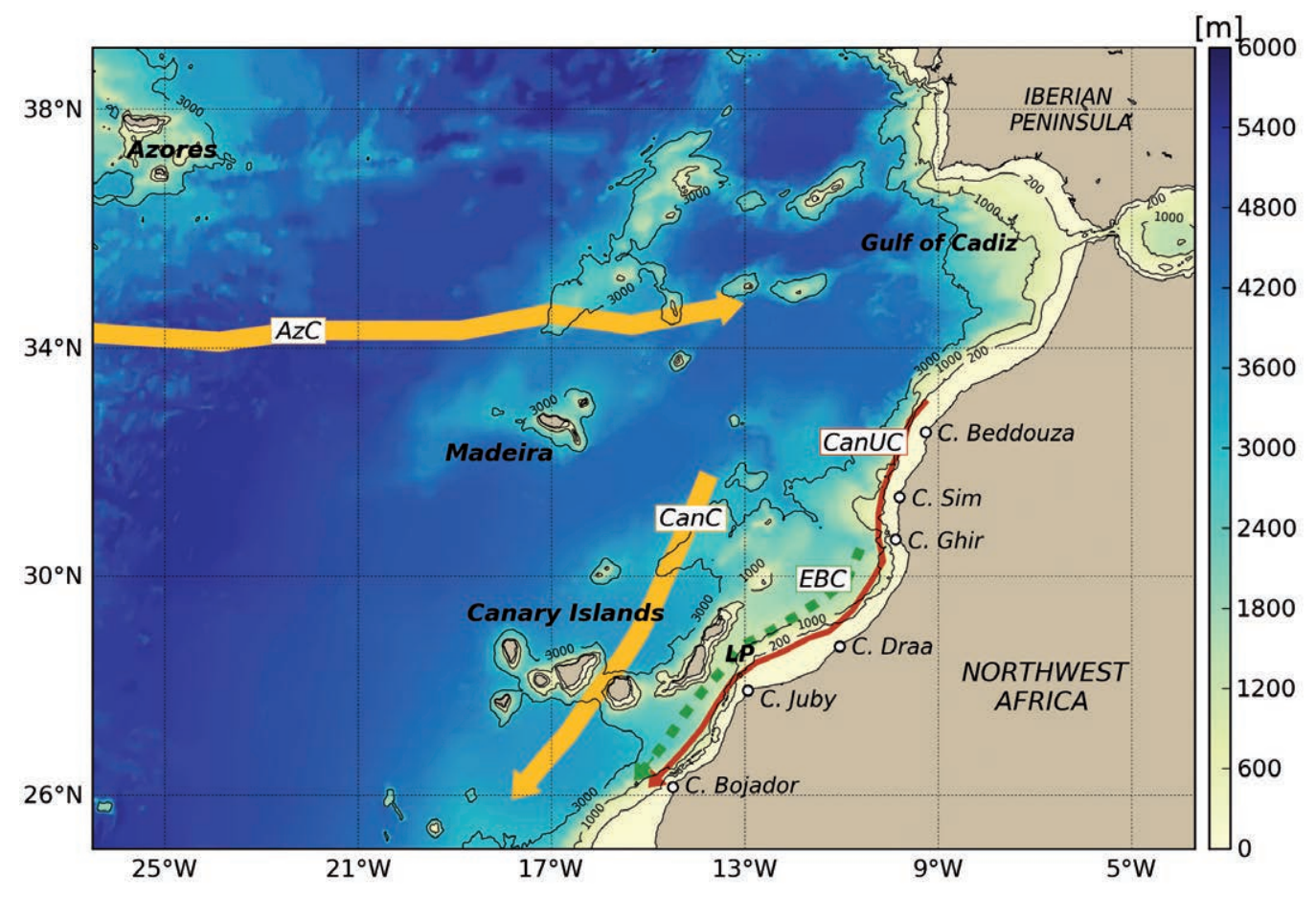

FIG. 1. - Schematic map showing topography and mean surface current structure of the Canary Upwelling System off northwest Africa. Key: AzC, Azores Current; CanC, Canary Current; CanUC, Canary Upwelling Current; EBC, Eastern Boundary Current (the EBC is shown dashed because it reverses to a poleward direction in autumn; see the Introduction for an explanation of the distinction between the EBC and CanUC); LP, Lanzarote Passage. Contours in black mark isobaths at 200, 1000 and 3000 m; topographic data obtained from GEBCO (Hunter and Macnab, 2003). A colour version of this figure may be found in the online electronic manuscript. 
(a) ROMS SST

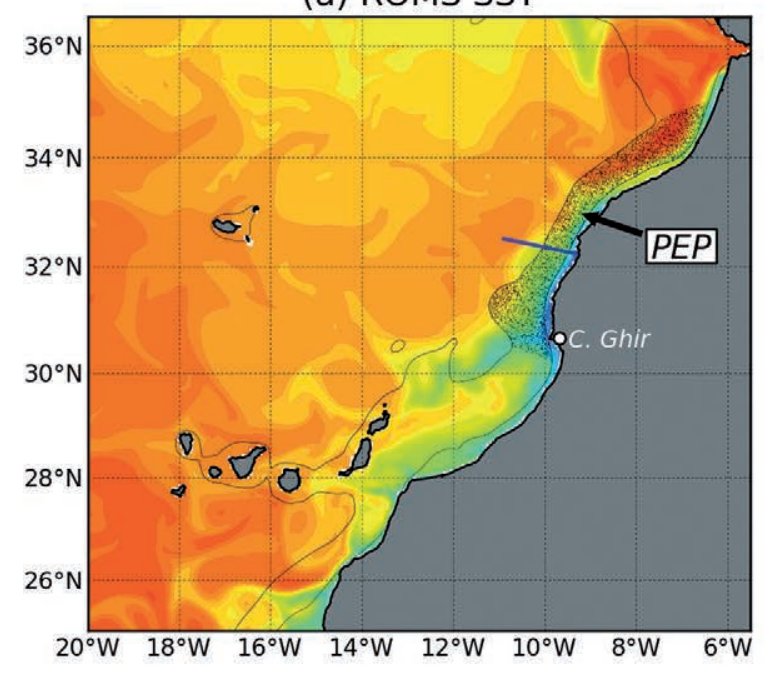

(b) ROMS temperature at $32.4^{\circ} \mathrm{N}$

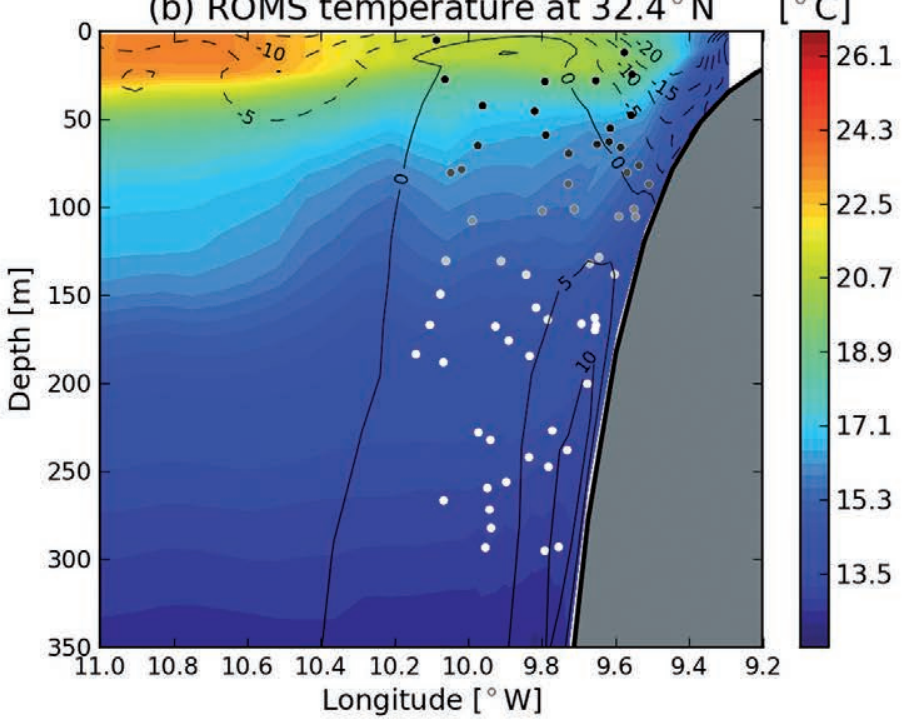

FIG. 2. - Random distribution of particle release locations (labelled PEP) within the target zone, and ROMS temperature on 29 August ROMS model year 44. (a) Snapshot of SST showing upwelling and filament activity along the northwest African coast. Release locations of a subset $(5000)$ of the 80000 Lagrangian floats are indicated by black dots. The 100- and 2000-m isobaths are plotted in black. (b) Temperature section (blue line in (a) marks location) showing upwelling-associated uplifting of isotherms over the outer shelf. Black contours of meridional velocity $\left(\mathrm{cm} \mathrm{s}^{-1}\right)$ reveal the equatorward upwelling jet (CanUC) between the surface and $\sim 100 \mathrm{~m}$, and the return-flowing slope current centred at $\sim 250 \mathrm{~m}$. Random float release locations are indicated by black (white) dots at surface (depth).

variability is thought to arise primarily from variations in the nearshore wind stress curl, although meridional current variability (i.e. EBC reversals) may also play a role (Siedler and Finke 1993, Mason et al. 2011). The cape itself is associated with the near-permanent Cape Ghir upwelling filament that can be seen extending hundreds of kilometres offshore in satellite sea surface temperature (SST) images (Van Camp et al. 1991, Pelegrí et al. 2005b).

Decadal variability of upwelling intensity, with important consequences for small pelagic fish productivity, was identified by Santos et al. (2005). GómezGesteira et al. (2008) highlighted a $45 \%$ reduction in the intensity of wind stress over the last 40 years. Longer-term implications for climate-change-related upwelling variability are also discussed by Bakun et al. (2010). However, these studies have focused on variability in local forcing, and it is unknown how changes in coastal upwelling may couple with possible changes in the circulation of the deep interior ocean. The Gulf of Cadiz region is particularly critical in this regard, because of its sensitivity to the exchange of Atlantic and Mediterranean waters that occurs at the Strait of Gibraltar (Ochoa and Bray 1991, Candela 2001, Mauritzen et al. 2001).

In order to study the dynamics of this complex region, a multi-year climatological hydrodynamic model configuration has recently been developed (Mason 2009, Mason et al. 2011). The aims of the present work are to use velocity outputs from the hydrodynamic model to determine the origins of water particles that reach the upwelling region north of Cape Ghir, by means of an offline particle-tracking Lagrangian model. Given the sensitivity of the slope waters and the underlying ecosystem to the forcing wind fields, it is of significant interest to understand how the recirculation paths may change under different forcing conditions. This can help to understand the character of the coupling between the deep and coastal oceans, as well as the intensity of the exchange between surface and upper thermocline layers.

Figure 2 focuses on the study region, showing a snapshot of the hydrodynamic model temperature in August. The upwelling is revealed in the SST as a narrow band of relatively cool waters along the coast (Figure $2 \mathrm{a}$ ). Cool water filaments extend offshore at the important capes, the most prominent being the Cape Ghir filament. This scene is typical of SST patterns observed from space (e.g. Barton et al. 1998). The vertical temperature section in Figure $2 b$ shows the uplifting of modelled isotherms with proximity to the coast. Contours of meridional velocity show the CanUC centred over the shelf edge. Below the CanUC at about $250 \mathrm{~m}$ is the return-flowing slope current (Barton 1989).

The paper is organised as follows. In the next section the hydrodynamic and Lagrangian model configurations are described. The results are then presented, followed by a brief discussion and conclusions.

\section{MODEL SETUP}

\section{The hydrodynamic model (Eulerian)}

A 50-year climatological Regional Ocean Modelling System (ROMS; Shchepetkin and McWilliams 2005, 2009) solution of the Canary Basin forms 
(a) Winter

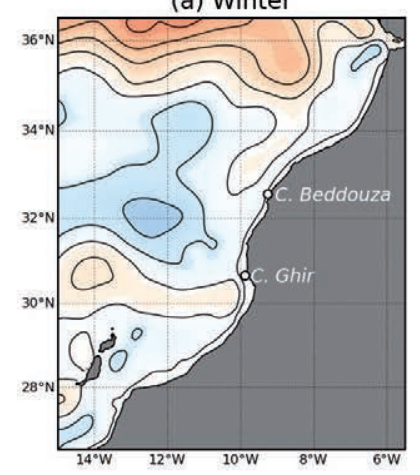

(b) Spring

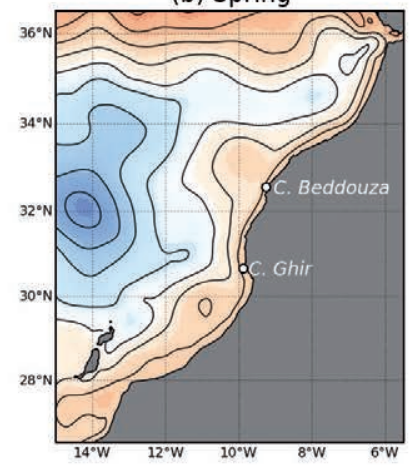

(c) Summer

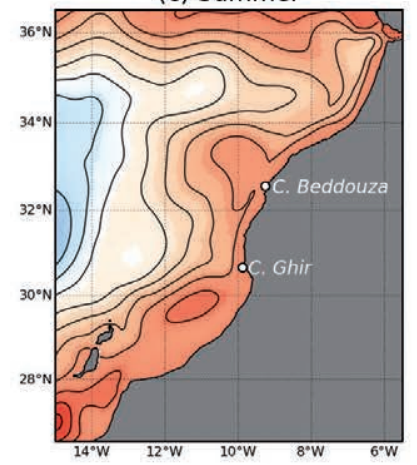

(d) Autumn

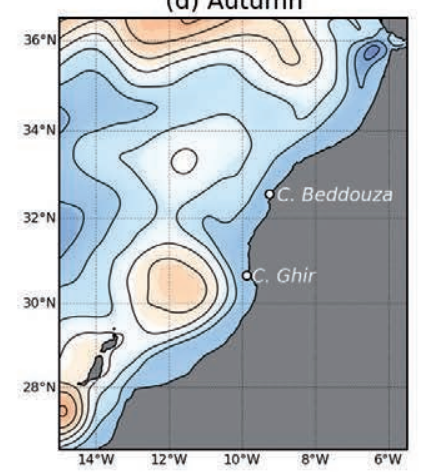

FIG. 3. - Seasonal depth-averaged $(0-300 \mathrm{~m})$ streamfunction $(\Psi)$ from the $7.5-\mathrm{km}$ ROMS solution. Blues (reds) represent positive (negative) $\Psi$; flow along positive closed $\Psi$ isolines is clockwise and vice-versa. Contours are spaced $0.5 \mathrm{~Sv}$ apart. A colour version of this figure may be found in the online electronic manuscript.

the basis for the Lagrangian experiments. The model configuration has a horizontal resolution of $7.5 \mathrm{~km}$, and 32 vertical terrain-following sigma levels with increased resolution between the surface and the thermocline. At the surface the model is forced using $0.25^{\circ}$ monthly mean wind stress from SCOW (Scatterometer Climatology of Ocean Winds, based on QuikSCAT; Risien and Chelton 2008). Heat fluxes and precipitation are supplied by COADS (Comprehensive Ocean Atmosphere-Dataset; Worley et al. 2005). At three open-ocean boundaries, monthly mean tracers from the temperature-salinity climatology of Troupin et al. (2010) and geostrophic velocity computed using the Troupin et al. data in conjunction with a climatology of absolute dynamic topography from AVISO (Archiving, Validation and Interpretation of Satellite Oceanographic data; Rio and Hernández 2004, Pascual et al. 2006) are imposed. The fourth open boundary at the Strait of Gibraltar is parameterized as described by Mason (2009). The development of this ROMS configuration is documented by Mason (2009) and Mason et al. (2010, 2011). The solution has been extensively validated through comparison with instantaneous- and mean-field observations of SST, drifter-derived surface velocities, and sea surface height anomalies and variances from altimetry. The simulation is shown to reproduce the important large-scale currents of the $\mathrm{Ca}-$ nary Basin (i.e. the $\mathrm{AzC}, \mathrm{CanC}$ and North Equatorial Current) and has realistic levels of mesoscale variability (Mason et al. 2011).

Two types of velocity output from the ROMS solution are used to force the Lagrangian model. Long-term seasonal means computed from years 1150 of the ROMS solution are used for climatological experiments. High-frequency variability is provided by three-day averaged ROMS outputs; these are used in a sequence of interannual experiments. Note that yearto-year variability in the ROMS solution is present and corresponds to intrinsic mesoscale variability generated by the model (see Marchesiello et al. 2003); this variability is not related to any particular time period.

\section{Mean model circulation and upwelling}

Figure 3 shows the depth-averaged (0-300 m) seasonal mean streamfunction in the study region computed from the ROMS solution; see Penven et al. (2005) and Mason et al. (2011) for the method of calculation of the streamfunction. Zonal streamlines that are present all year north of about $34.5^{\circ} \mathrm{N}$ correspond to the AzC. The path of the equatorward CanC is readily apparent in summer. Over the course of the year the CanC undergoes extensive meandering, which is a consequence of the westward passage of planetary-wave-like anomalies generated near the eastern boundary that radiate offshore and perturb the current (Hagen 2001, Mason et al. 2011). Wave-like structure is most clearly seen in winter along $31^{\circ} \mathrm{N}$; the two closed contours just north and south of this parallel suggest a winter westward diversion of the mean CanC. The southern anomaly originates south of Cape Ghir in spring, but is largest in autumn when it is responsible for strong offshore transport at Cape Ghir (Fig. 3d). The well-documented annual reversal of the large-scale coastal flow is evident in autumn (Machín et al. 2006a, Machín and Pelegrí 2009, Fraile-Nuez et al. 2010).

In Figure 4 we examine the model's response to alongshore wind forcing. Classical two-dimensional coastal upwelling theories indicate that normal-toshore Ekman transport results in vertical transport over some near-shelf region. But to what extent does the model response fit with this two-dimensional view? With this question in mind we define a normalized upwelling velocity, which compares actual (numerical) vertical upwelling with the offshore transport induced by Ekman forcing. Ignoring alongshore variations and using the coastal constraint (i.e. no normal transport at the coast), the vertical velocity at the base of the surface mixed layer (which is assumed to approximately coincide with the surface Ekman layer) is given by $w_{E}=-\tau_{y} /\left(\rho f L_{x}\right)$, where $\tau_{y}$ is the model alongshore wind stress at the sea surface ( $\tau_{x}$ is assumed zero), $\rho=1026$ $\mathrm{kg} \mathrm{m}^{-3}$ is water density, $f=7.7 \times 10^{-5} \mathrm{~s}^{-1}$ is the Corio- 
(a) Annual upwelling, $\hat{w}_{b}$

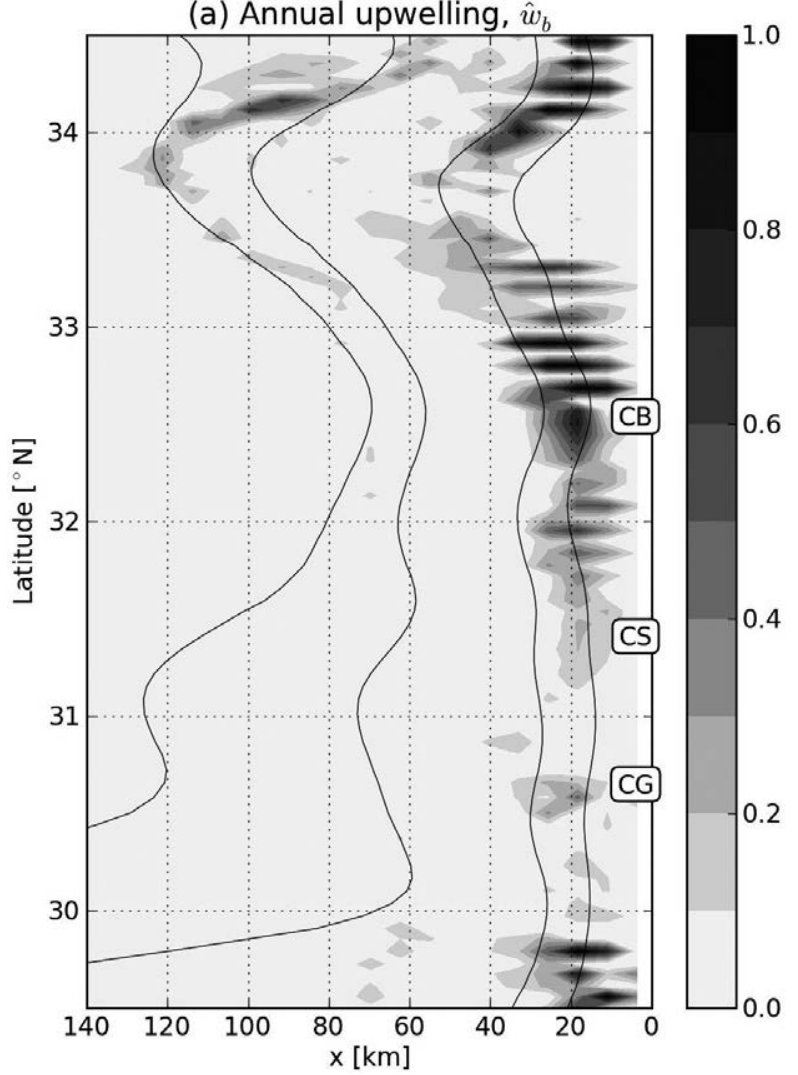

(c) Monthly upwelling, $\hat{w}_{b}\left(32.0^{\circ}-33.0^{\circ} \mathrm{N}\right)$

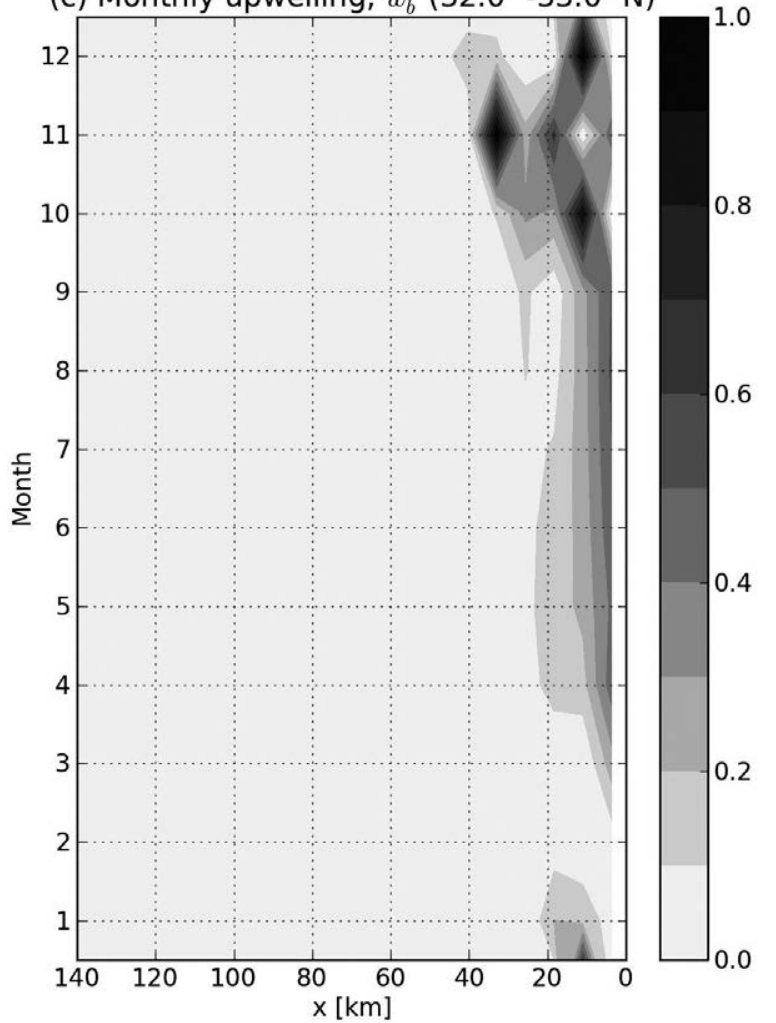

(b) Annual integrated upwelling, $\hat{w}$

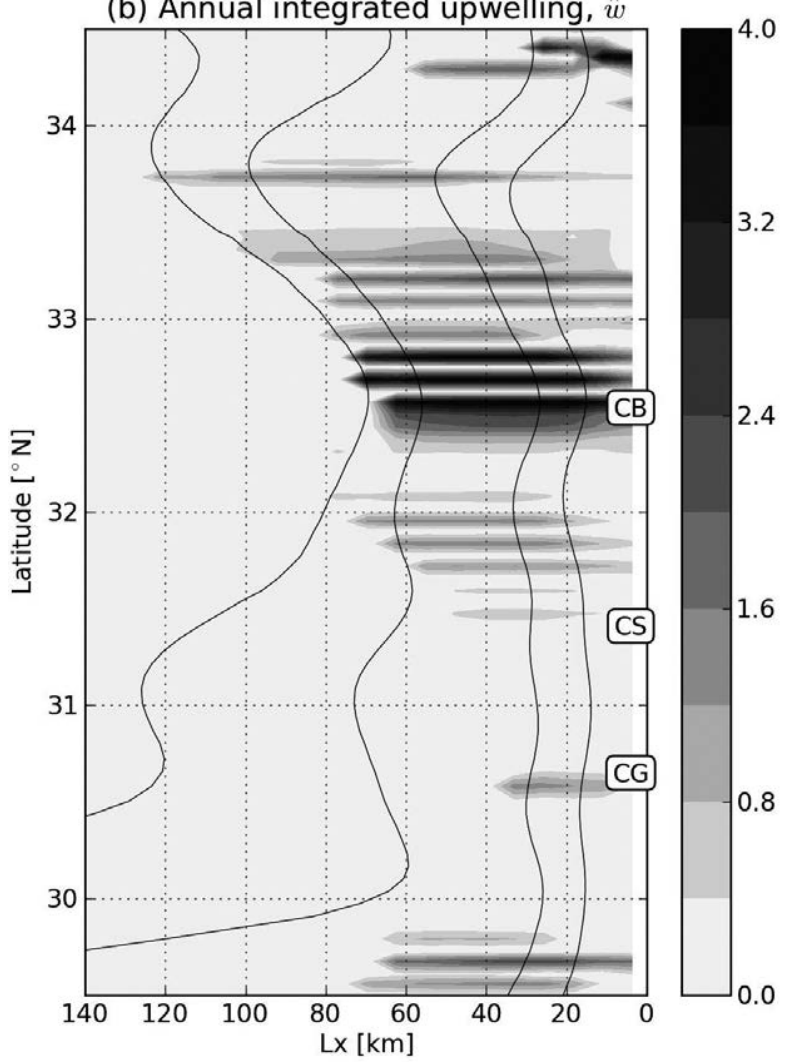

(d) Monthly integrated upwelling, $\hat{w}\left(32.0^{\circ}-33.0^{\circ} \mathrm{N}\right)$

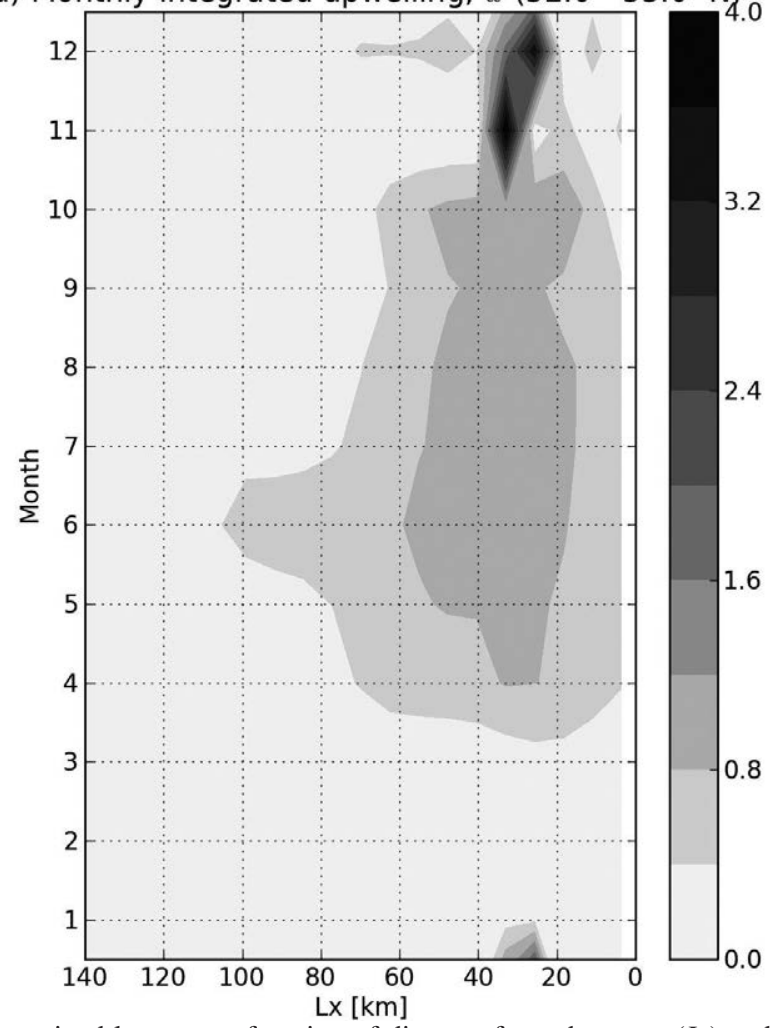

FIG. 4. - (a) Annual mean normalised upwelling velocity, $\hat{w}_{b}$, just below the mixed layer, as a function of distance from the coast $\left(L_{x}\right)$ and latitude. Capes Ghir, Sim and Beddouza are labelled. Line contours show model grid isobaths at 100, 200, 2000 and $3000 \mathrm{~m}$. (b) Same as (a) but considering the offshore integrated upwelling velocity, $\hat{w}$. (c,d) Same as $(\mathrm{a}, \mathrm{b})$ but showing monthly variability averaged between $32^{\circ} \mathrm{N}$ and $33^{\circ} \mathrm{N}$. Note the use of different scales for the grey-colour bars. 
lis parameter, and $L_{x}$ is the extent of the coastal band over which upwelling takes place (approximately the distance between the shelf-break and the sea surface signature of the coastal upwelling frontal system). Therefore, we can obtain the normalized model vertical velocity as:

$$
\hat{w}_{b}=\frac{w_{b} \Delta x}{w_{E} L_{x}}=\frac{\rho f w_{b} \Delta x}{\tau_{y}}
$$

with $\Delta x \approx 7.5 \mathrm{~km}$ the model grid cell size. In this expression the vertical velocity is taken from the model output at a depth close to the base of the surface mixed layer, $w_{b}=w\left(z=z_{b}\right)$. Notice that this vertical velocity is nothing more than a normalized indicator of those locations where upwelling is most intense, it being a function of the grid cell size.

We may also define an integrated normalized vertical velocity, which includes all of these vertical transport contributions when moving offshore from the shelf. This quantity may be expected to increase with offshore distance through the active upwelling region, and to remain constant or decrease beyond. The (cross-shore) integrated normalized vertical velocity is defined as:

$$
\hat{w}=\frac{\int_{0}^{-L_{x}} w_{b} d x}{w_{E} L_{x}}=\frac{\rho f \int_{0}^{-L_{x}} w_{b} d x}{\tau_{y}}
$$

which is no longer a function of $\Delta x$. This quantity, normalized by the amount of upwelling potentially driven by the wind, can tell us how efficient the wind is at actually driving subsurface waters to the near-surface. If $\hat{w}$ is much less than one then upwelling will be largely suppressed; if it exceeds one then other non-winddriven processes are at play to induce upwelling.

Contours of $\hat{w}_{b}$ and $\hat{w}$ between $29.5^{\circ} \mathrm{N}$ and $34.5^{\circ} \mathrm{N}$ are shown in Figures $4 \mathrm{a}, \mathrm{b}$, calculated at $z_{b}=M L D-10$ $\mathrm{m}$, using annual means of the respective model data ( $M L D$ is the model mixed layer depth obtained from the ROMS KPP vertical mixing scheme of Large et $a l$. 1994). The normalised vertical velocity $\hat{w}_{b}$ displays abrupt changes at the submesoscale (i.e. over distances of less than $10 \mathrm{~km}$ ) as a function of latitude and crossshore distance (Fig. 4a). Elevated nearshore values are linked to Cape Ghir and, especially, Cape Beddouza. This is in partial agreement with the upwelling index of Marcello et al. (2011), which shows intense upwelling around Cape Ghir in summer and autumn, but emphasizes the important role played by Cape Beddouza to induce local upwelling. In most of the domain upweling takes place between the 100 and $200 \mathrm{~m}$ isobaths but between $32.5^{\circ} \mathrm{N}$ and $34^{\circ} \mathrm{N}$, coinciding with a slightly flatter topographic slope at the southern reaches of the Gulf of Cadiz, moderate upwelling extends as far as $120 \mathrm{~km}$ offshore into deep waters. In the latitudinal extremes of our study area, north of $34^{\circ} \mathrm{N}$ and south of $30^{\circ} \mathrm{N}$, annual-mean upwelling is reinforced. Informa- tion from upwelling observations and indices in this region seems to be contradictory (Arístegui et al. 2009), although particularly high offshore clupeid spawning has been reported by Roy et al. (1989).

In order to display the integrated normalized vertical velocity, $\hat{w}$, the cross-shore integration is run only while $\hat{w}_{b}$ remains above some specified threshold over a sufficiently long distance. Here we have selected this distance to be 13 grid cells $(\approx 100 \mathrm{~km})$, which is substantially larger than a two-layer internal Rossby radius for this region, of order $10 \mathrm{~km}$ (e.g. Benítez-Barrios et al. 2011), and $5.0 \times 10^{-6} \mathrm{~m} \mathrm{~s}^{-1}\left(0.43 \mathrm{~m} \mathrm{day}^{-1}\right)$ for the threshold velocity, which is one order of magnitude smaller than moderate upwelling values (e.g. BenítezBarrios et al. 2011). In this way we disregard weak upward vertical velocities that may occur in the interior ocean and are not related to the coastal constraint. The annual-mean $\hat{w}$ value indicates the existence of abrupt submesoscale along-shore changes and displays a prominent maximum around Cape Beddouza. Upwelling remains active until about 60 to $120 \mathrm{~km}$ from shore, essentially covering the whole continental slope, this being an estimate of the width of the upwelling area (Fig. 4b).

The temporal variability of the normalised vertical velocity is assessed in the region near Cape Beddouza, between 32 and $33^{\circ} \mathrm{N}$, where annual-mean upwelling is maximum (Figs. 4c,d). The monthly distribution of $\hat{w}_{b}$ shows the upwelling is confined all year within a $40 \mathrm{~km}$ coastal band. Upwelling does not conform to the expected pattern of maximum summer values following the increase in the northeasterly winds. Instead, normalised vertical velocity is maximum in autumn and early winter and disappears suddenly in late winter. This result is in agreement with observations by Marcello et al. (2011), who report coastal upwelling north of $33^{\circ} \mathrm{N}$ in autumn and winter. The moderate spring and summer values suggest a progressively inhibiting role of increased stratification as the winds increase. This behaviour ceases suddenly in autumn, probably a result of the combination of intense winds and decreased stratification near the base of the mixed layer but may also be the outcome of enhanced horizontal convergence following the maximum northward extension of the EBC reversal.

The monthly distribution of $\hat{w}$ within the $32-33^{\circ} \mathrm{N}$ band shows that moderate upwelling occurs during the April-October period (Fig. 4d), with a maximum at about $50 \mathrm{~km}$ from shore; during these months the maximum offshore extension is about 60 to $70 \mathrm{~km}$, reaching $100 \mathrm{~km}$ in June. In contrast, the late autumn (November and December) maximum values take place entirely between 20 and $40 \mathrm{~km}$ from shore, that is between the 100 and $200 \mathrm{~m}$ isobaths.

The above calculations emphasise the temporal and spatial dependence of the upwelling. When averaged in time and space, upwelling is indeed of the order of the values expected from the alongshore wind forcing, but this is not the case at any particular time or position. 
TABLE 1. - Details of the Lagrangian experiments. Key: IAnn/Clim, Interannual/Climatology; Fo/Ba, Forwards/Backwards.

\begin{tabular}{|c|c|c|c|c|c|c|}
\hline Experiment & IAnn/Clim & $\mathrm{Fo} / \mathrm{Ba}$ & Release day & Release season & Release year* & Length [days] \\
\hline 1 & Clim & $\mathrm{Ba}$ & 45 & Win & $\mathrm{n} / \mathrm{a}$ & 1080 \\
\hline 2 & Clim & $\mathrm{Ba}$ & 135 & Spr & $\mathrm{n} / \mathrm{a}$ & 1080 \\
\hline 3 & Clim & $\mathrm{Ba}$ & 225 & Sum & $\mathrm{n} / \mathrm{a}$ & 1080 \\
\hline 4 & Clim & $\mathrm{Ba}$ & 315 & Aut & $\mathrm{n} / \mathrm{a}$ & 1080 \\
\hline $5(9)$ & IAnn & $\mathrm{Ba}$ & 45 & Win & $35(45)$ & 720 \\
\hline $6(10)$ & IAnn & $\mathrm{Ba}$ & 135 & Spr & $35(45)$ & 720 \\
\hline $7(11)$ & IAnn & $\mathrm{Ba}$ & 225 & Sum & $35(45)$ & 720 \\
\hline $8(12)$ & IAnn & $\mathrm{Ba}$ & 315 & Aut & $35(45)$ & 720 \\
\hline 13 & IAnn & Fo & 45 & Win & 35 & 720 \\
\hline 14 & IAnn & Fo & 135 & Spr & 35 & 720 \\
\hline 15 & IAnn & Fo & 225 & Sum & 35 & 720 \\
\hline 16 & IAnn & Fo & 315 & Aut & 35 & 720 \\
\hline
\end{tabular}

Release year is not applicable for climatological forcing.

Upwelling can be zero at many coastal locations while, in a few instances, it may become quite high, as if all the wind-induced offshore transport were recirculating vertically within cross-shore cells no larger than a few grid-points. The cross-shore integrated upwelling actually reaches values nearly four times the Ekman offshore transport in relatively large regions near Cape Beddouza.

\section{The Lagrangian experiments}

A Lagrangian drifter-tracking code is used to simulate water parcel trajectories using the stored ROMS three-dimensional velocity fields, $\vec{u}=(u, v, w)$. The tracking code is ROMS Offline (Roff, version 2.0.1; Capet et al. 2008, Carr et al. 2008). Similar approaches using Roff have been taken by Carr et al. (2008) for the US West Coast, and Montes et al. (2010) for Peru/ Chile. At the Canary Islands, Brochier et al. (2011) use a Lagrangian model to study pelagic egg and larval transport from the coast to the islands. Also notable is the recent Lagrangian study of the California upwelling off the Oregon coast by Rivas and Samelson (2011). Roff permits both forwards-in-time and backwards-intime simulations of particle trajectories starting from a pre-defined release area. Backwards runs enable determination of the source regions of the particles. In the following, when discussing the backwards runs we use a forwards-in-time perspective. Hence, the terms particle initial position (PIP) and particle end position (PEP) will refer to particle locations at the end and beginning of the backwards simulations, respectively.

Figure 2 includes the PEP float release zone off the northwest African coast: a total of 80000 floats are released randomly between 0-300 $\mathrm{m}$ depth over the continental shelf and slope, within the limits $30.5-35^{\circ} \mathrm{N}$ and an area delimited by the 100- and 2000-m isobaths. The intention is to concentrate on the upwelling and frontal regions, their extension depending on the intensity of the varying winds but probably not extending much beyond the 2000-m isobath. The coastal front and the associated baroclinic jet move onshore/offshore over the slope as a result of the varying winds, causing the coastal upwelling band to widen/shrink. This is the area where vertical exchange is most intense, either through epipycnal (along-isopycnal) motions following outcropping isopycnals or through diapycnal (cross-isopycnal) mixing related to shear-induced vertical instabilities in the coastal upwelling baroclinic jet.

In total 16 experiments were performed (Table 1), of which four were climatological runs (runs 1-4) forced by seasonal mean velocities, while the remainder (runs 5-16) were interannual experiments that utilized high-frequency velocities; the high-frequency velocities were three-day averages corresponding to the ROMS solution years 33-35 (runs 5-8). A second set of interannual experiments (runs 9-12), using ROMS years 43-45, were carried out to demonstrate the presence of variability between years. All but four of the experiments were backwards-in-time experiments; runs 13-16 were forwards-in-time. Particle positions were stored every two days. For the time period of the experiments, the ROMS model domain is sufficiently large such that all floats remain within the domain. The experiments are categorized according to their forcing (by high-frequency velocities or seasonal mean velocities), direction (forwards or backwards), release date (i.e. season), and length of the simulation (in days).

\section{RESULTS}

Analysis of the results is facilitated by filtering the float trajectories according to time, duration, and horizontal and vertical position. In this paper we concentrate on the backwards runs, which provide information about the source regions of water parcels found within the release zone. We consider only trajectories from particles released within a target area between $31^{\circ} \mathrm{N}$ and $34^{\circ} \mathrm{N}$ (black bold outline in Fig. 5). This region is chosen because it is considered important for cross-shore exchange with the open ocean (Laiz et al., 2001; Machín et al., 2006b), and is just north of the potential natural boundary constituted by the filament at Cape Ghir $\left(30.6^{\circ} \mathrm{N}\right)$.

We examine two depth levels, specified at 0-40 m and $40-300 \mathrm{~m}$; the $40-\mathrm{m}$ interface is typical of the annual mean MLD in this region. Above the 40-m level the water is expected to move offshore as a result of 

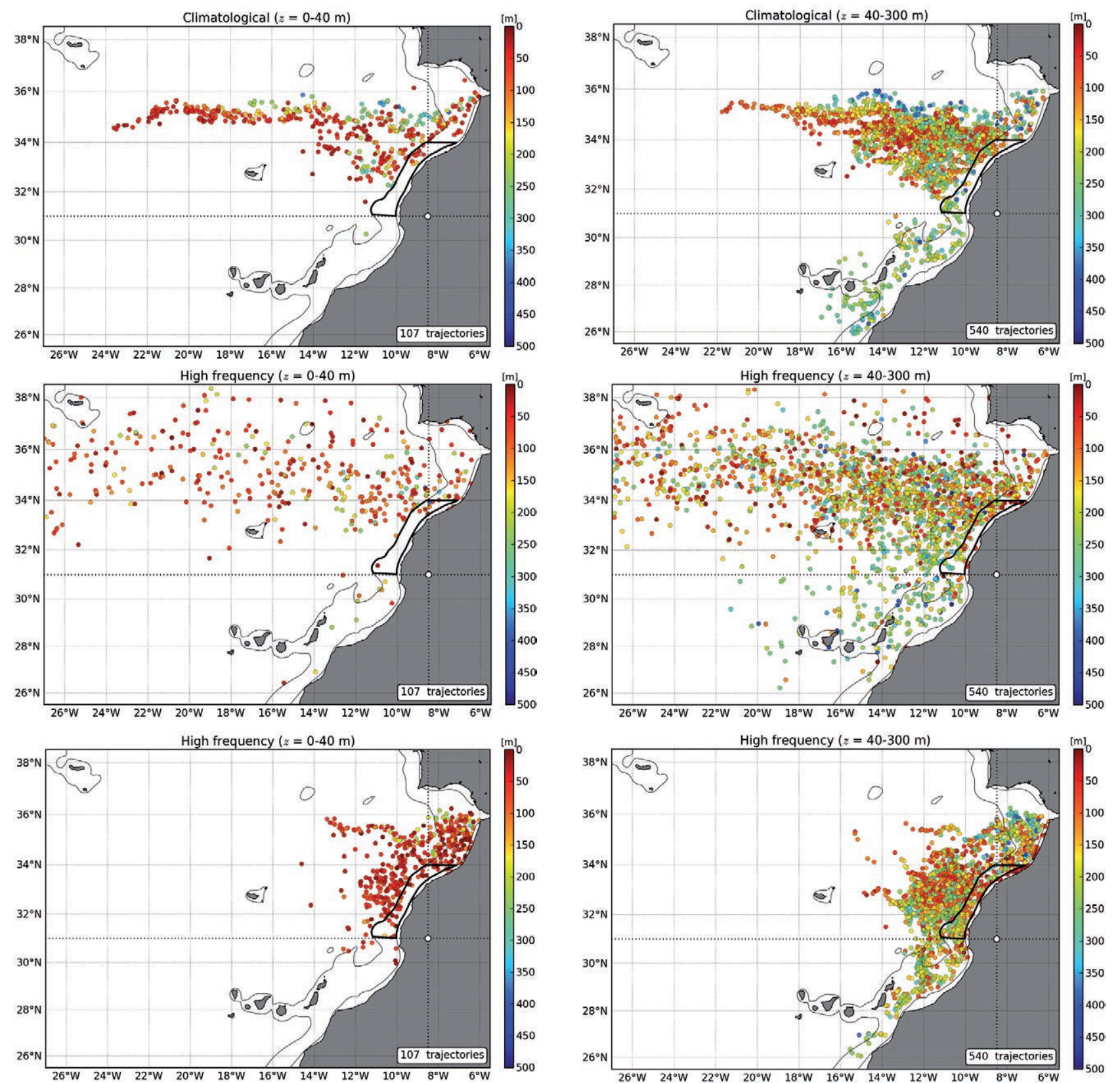

FIG. 5. - Float positions after 360 days backwards integration from the (a,b) climatologically-forced runs (1-4; see Table 1) and (c,d) highfrequency forced runs (5-8; see Table 1); 90-day high frequency positions are shown in (e,f). Symbol colour indicates particle depth. Arrivals at the target area (outlined by thick black line) are shown for (left panels) 0-40 m and (right panels) 40-300 m releases. Dotted black lines indicate the positional filters used in the text. The 100- and 2000-m isobaths are demarked by thin black lines.

Ekman transport. On the other hand, in the 40-300 m range most water is expected to come from the interior ocean and recirculate along-slope as the CanUC (Pelegrí et al. 2005a). In fact, only $10 \%$ of the floats released in the target area are found within the 0-40 m layer; this figure increases to $52 \%$ for the $40-300 \mathrm{~m}$ layer.

\section{Major pathways to the upwelling region}

Figure 5 shows PIP distributions of $(a, b)$ climatologically forced and $(c, d)$ high-frequency-forced trajectories after 360 days of backwards advection, and (e,f) the same high-frequency trajectories after 90 days of advection. Symbol colour corresponds to depth. The subfigures in the left panel $(\mathrm{a}, \mathrm{c}, \mathrm{e})$ show particles released from the target area between 0 and $40 \mathrm{~m}$, while those to the right (b,d,f) show 40-300 m releases. Considering first the climatological trajectories (Figs. $5 \mathrm{a}, \mathrm{b}$ ), three main pathways leading to the release zone can be easily identified:

An offshore pathway from the northwest. This pathway is the dominant pathway, crossing the Canary Basin at $\sim 35^{\circ} \mathrm{N}$, in clear association with the $\mathrm{AzC}$. At its western extent, particles at depths between the 
surface and $\sim 100 \mathrm{~m}$ are prevalent, indicating stronger advection in the surface layer. It is noteworthy that the deeper water sources $(>300 \mathrm{~m})$ tend to be located along the northern boundary of the AzC. Eastward of $\sim 15^{\circ} \mathrm{W}$, trajectory terminations are found in the Gulf of Cadiz and in the region of the CanC. A large fraction of the 40-300 m particles depart from the near-surface layer; we will see later that this occurs in winter, when both winter convection in the surface mixed layer and surface Ekman pumping are capable of driving water parcels in the mixed layer into the thermocline anticyclonic circulation (Stommel 1979).

A northern pathway from the Gulf of Cadiz to the northeast, where particles generally flow alongshore following the shelf and slope. The source of these particles for timescales greater than 360 days may be expected to be the $\mathrm{AzC}$, but an examination of 720 day trajectories (not shown) shows a similar number of particle terminations, suggesting that particles may be caught in strong recirculations within the Gulf of Cadiz over significant periods of time (Fig. 3).

A southern pathway that traverses the LP and the Canary Islands. This pathway may play a role all year through the action of the poleward undercurrent but it is expected to be particularly important in autumn when the EBC reverses to poleward flow. The southern pathway is only seen in the 40-300 m release trajectories, an indicator of the importance of southward wind-drift in the surface layers. The southern and northern pathways may be grouped together as alongshore pathways.

The trajectories in Figure 5 indicate that one year after their release some particles remain relatively near to or even within the target zone. This is perhaps not surprising for the high-frequency simulations (Figs. $5 c, d)$, in which mesoscale variability may be expected to hinder the progress of a significant proportion of the particles towards the target zone. However, mesoscale variability is removed from the climatological simulations (Figs. 5a,b), suggesting that other processes are at work in these simulations; we surmise that the planetary wave activity outlined above (Subsection The hydrodynamic model), which is responsible for the existence of closed trajectories (loops) west of Cape Ghir, may have a significant influence on the paths of the climatological particles.

As may be expected, the high-frequency trajectories show considerable scatter in comparison with the climatological trajectories. However, in Figure 6 we show that, quantitatively, the mean climatological (experiments 1-4 of Table 1) and high-frequency pathways (experiments 5-8 and 9-12) are little altered. A simple filter is applied by counting trajectories that originate within three quadrants: offshore, northern and southern (defined by the black dotted meridional and zonal lines that intersect at $31^{\circ} \mathrm{N}, 8.5^{\circ} \mathrm{W}$ in Figure 5). The results, from samples of 47000 floats in the depth range 0-300 $\mathrm{m}$, show that percentage annual and seasonal mean contributions to each pathway remain largely equal regardless of the forcing imposed.

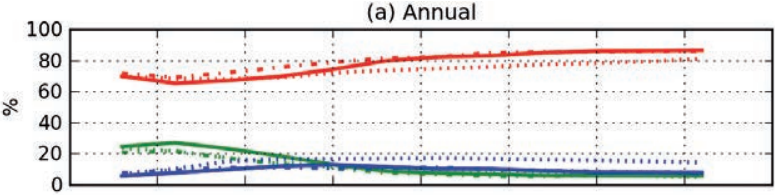

(b) Winter
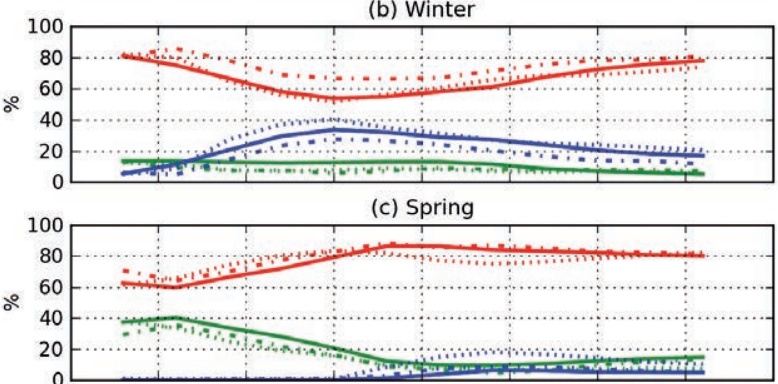

(d) Summer
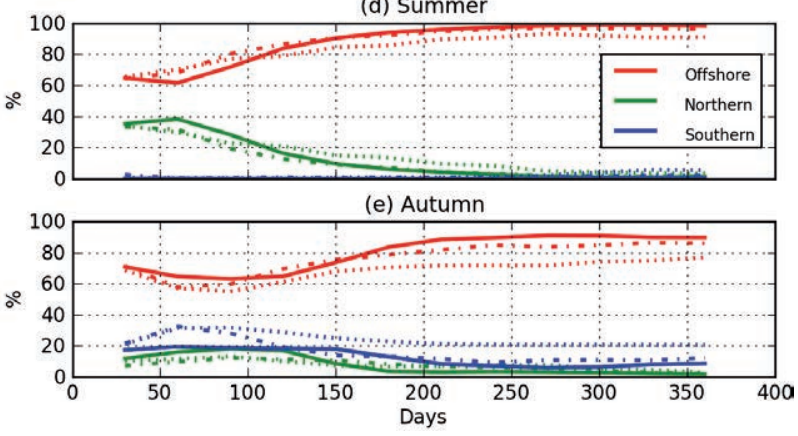

FIG. 6. - Plots comparing the (a) annual and (b-e) seasonal particle percentage contributions from the three pathways (offshore in red, northern in green, southern in blue) that lead to the target area identified in Figure 5, as a function of time from release in days. Full curves correspond to the climatological runs (experiments 1-4), dash-dot and dotted curves correspond to the respective sets of high frequency runs (experiments 5-8 and 9-12). Sample sizes are 47000 floats, for a depth range of 0-300 m. A colour version of this figure may be found in the online electronic manuscript.

The curves in Figure 6 illustrate the dominance of the offshore pathway for the transport of particles into the target zone. However, the magnitude of this dominance is a function of time. For timescales greater than 200 days, the annual mean offshore contribution exceeds $80 \%$, with the remainder made up from the northern and southern pathways. At shorter timescales contributions from the north and south have greater significance. For example, Figure $6 \mathrm{c}$ shows that the greatest contribution from the northern pathway (i.e. Gulf of Cadiz), $\sim 40 \%$, occurs at about 60 days; this corresponds to mid-March, consistent with the increase in upwelling around this time between $32^{\circ} \mathrm{N}$ and $34^{\circ} \mathrm{N}$ shown in Figure $4 d$. For the southern pathway, the peak contribution (near $40 \%$ ) occurs in the winter solutions at around 150 days (Fig. 6d); this corresponds to midSeptember which, while early for the EBC reversal, is a period of increasing cyclonic flow along the coast between the LP and Cape Ghir (Figs. 3c,d).

Figure 6 also reveals some noteworthy differences between the two sets of high-frequency trajectories. The largest differences occur in autumn and winter for both the offshore and southern pathways. Differences in the south are probably linked to high mesoscale vari- 
ability at the Canary Islands, the LP, and Cape Ghir; seasonal fields of ROMS eddy kinetic energy (EKE) by Mason (2009) show significant increases of EKE in summer and autumn at these locations.

\section{Pathway variability at annual timescales}

Figure 7 allows a closer examination of surface pathway variability, by showing the mean pathways for 360-day backwards trajectories released at the near surface $(0-40 \mathrm{~m})$; note that this sample $(N=8033)$ represents just $10 \%$ of the total float release. Maps of the trajectories are shown (left column), and percentage contributions to each pathway are included in the corresponding legends. The offshore pathway contributes more than $80 \%$ of the sample in all seasons. This pathway tends to closely follow the axis of the $\mathrm{AzC}$ and enters the target zone from the north/northeast (cf. Fig. 5). However, a major southward diversion takes place in summer and is clearly visible in the winter mean path (cf. also Fig. 3c); this feature is consistent with the offshore intensification of the CanUC reported by Machín et al. (2006b). As a water parcel enters the upwelling region it turns southwest and the speed of the flow experiences a substantial increase, indicative of the swift currents associated with the CanUC. The northern pathway contribution in Figure 7 is generally small, exceeding $10 \%$ only in winter and spring. The southern pathway contribution in the 0-40 m layer is negligible and is not further discussed.

To assess depth variability along the particle paths as they approach the target zone, the right panel of Figure 7 shows changes in depth relative to the initial depth (i.e. PIP depth), $\Delta z$, for the 360-day trajectories. Both mean values and their standard deviations are shown. A rapid increase in $\Delta z$ implies a significant rate of upwelling. The main process that controls the rate of change of $\Delta z$ is coastal upwelling near the continental slope, as apparent by the rapid increases towards the end of the time series. In all mean paths, however, there are instances when the water parcels rise towards the surface while still located within the deep ocean. As this always occurs in winter, formation of the winter mixed layer is a plausible mechanism.

In contrast to Figure 7, Figure 8 shows trajectories filtered at $40-300 \mathrm{~m}$; the sample size is now $N=38985$, which is $52 \%$ of the total float release. In the left column, the pathways are shorter than the $0-40 \mathrm{~m}$ pathways, consistent with lower rates of advection away from the surface layers. The seasonal mean offshore pathways remain dominant and are seen to enter the target zone consistently from the northwest at around $32.5^{\circ} \mathrm{N}$ (cf. Figure 7, where they enter from the north/ northeast), and $\mathrm{AzC}$ origins are again evident. The approach to the target zone of each pathway is shaped by the seasonal mean circulation prior to arrival, as shown in Figure 3. The southern pathway at this deeper level has an increased importance in comparison with the surface (0-40 m) level, exceeding $13 \%$ in autumn and 360-day trajectories $(\mathrm{N}=8033)$
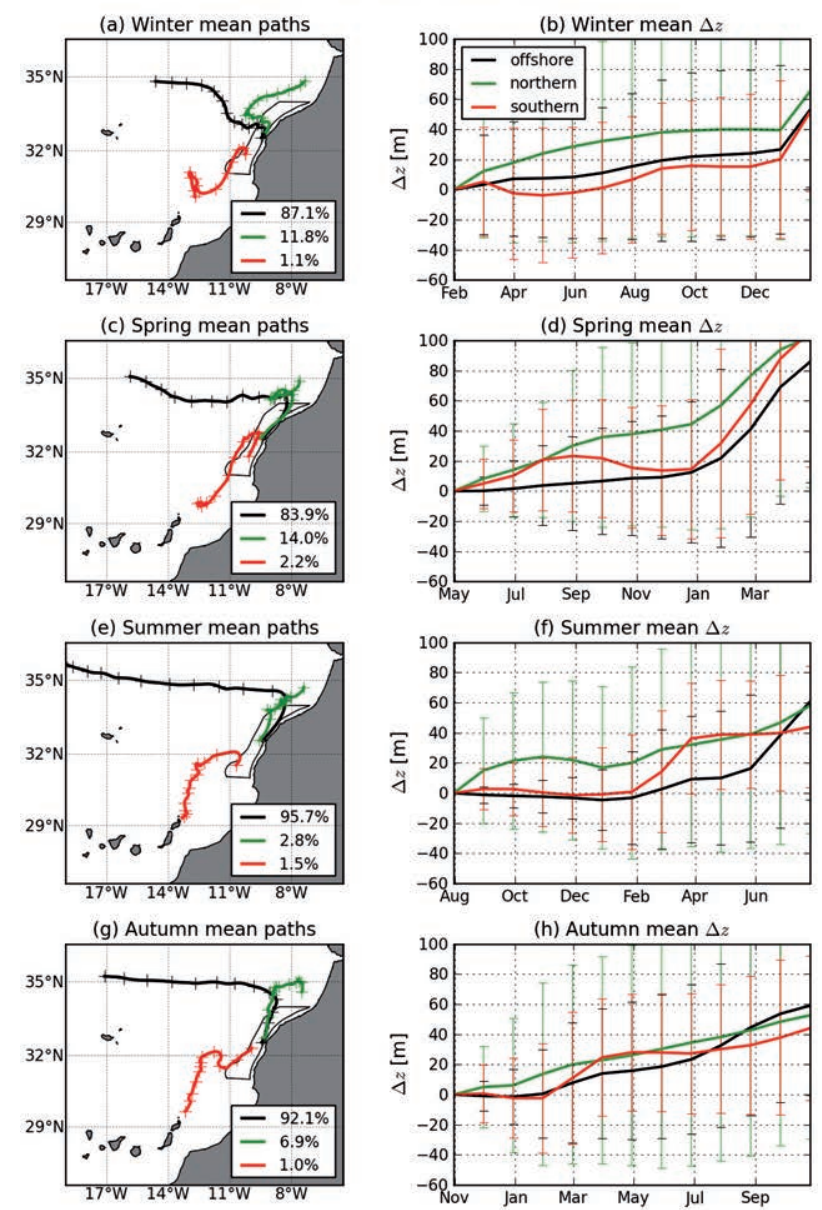

FIG. 7. - Seasonal mean (left panel) $\Delta z$ and standard deviation; and corresponding mean paths (right panel) for $0-40 \mathrm{~m}$ filtered trajectories representing offshore, northern, and southern pathways from backwards runs 5-8 (Table 1). The percentage contributions of the total sample $(N)$ to each pathway are given in the right panel legends, where it can be seen that the southern pathway is not significant in any season and can be neglected. The $\Delta z$ data are subsampled at a monthly frequency; the corresponding points for each month in the mean trajectory paths are indicated by "+".

winter. In spring the northern pathway is at its peak $(13.6 \%)$. In summer, the offshore pathway is responsible for more than $96 \%$ of the particle transport into the target area; the northern and southern pathways are insignificant.

The right column of Figure 8 shows $\Delta z$ depth variability for the 40-300 m pathways. Coastal upwelling is evident in the dominant offshore pathways as they approach the target zone; one exception occurs as the mean pathway enters the target area in December/January, when no increase in $\Delta z$ is apparent. Such a situation may simply be the effect of winter convection on the vertical velocities in the surface mixed layer; in the study area winter convection reaches some $200 \mathrm{~m}$ (Ratsimandresy et al., 2001) so it would induce positive/ negative vertical velocities in the upper/lower portion of the mixed layer. Regarding the southern pathway, $\Delta z$ shows significant variability while still distant from 
360-day trajectories $(\mathrm{N}=38985)$
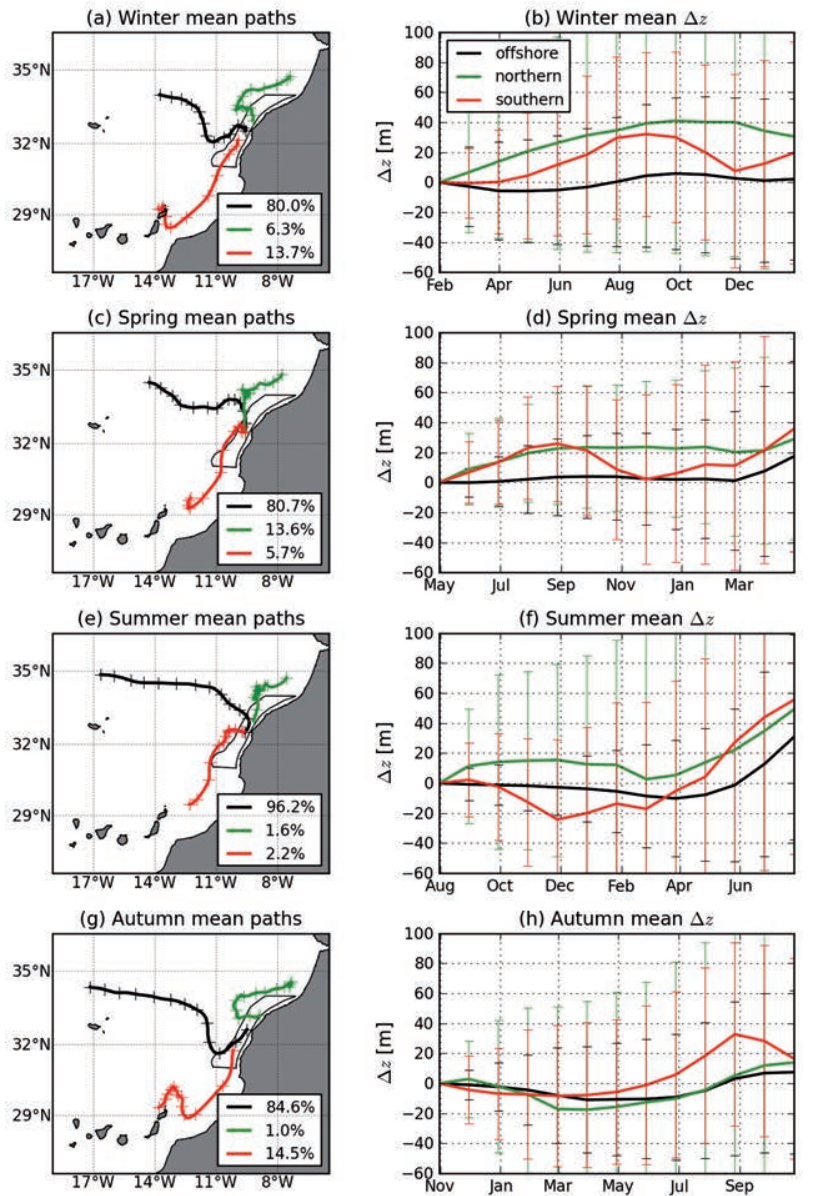

FIG. 8. - Same as Figure 7 but for $40-300 \mathrm{~m}$ filtered trajectories.

the target area: it systematically increases between April and September and falls between September and December. Examination of Figures 8a,g shows that, from February to August, particles following the mean pathway are essentially trapped within a small region around the north of Lanzarote (the northeasternmost Canary island). This result indicates that the southern pathway comprises not only water parcels from south of the Canary Islands, but that there is a significant contribution from the northern part of the archipelago, which appears to recirculate slowly until it enters the LP and is advected northwards within the reversed (i.e. poleward) EBC.

The results from Figures 7 and 8 emphasise the importance of the $\mathrm{AzC}$ as a source for the target region. Seasonal variability appears to be related to the change in regime along the western IP, between the southward flowing summer Portugal Current and the winter Iberian Poleward Current (IPC) (Peliz et al. 2005). During winter the IPC and CanUC combine to provide a meridionally-divergent region which drives the zonal flow into the eastern Gulf of Cadiz (Machín et al. 2006b). A significant observation is that summertime-released particles travel the greatest distances, with the parti- cles accelerating eastwards during the winter period. Nevertheless, most water parcels reach the upwelling region following the offshore path.

\section{Pathway variability at seasonal timescales: the upwelling region}

The offshore, northern and southern pathways defined in the two previous subsections (Major pathways to the upwelling and Pathway variability at annual timescales) converge within the release zone. Seasonal distributions of high-frequency-forced PEP between 0 and $300 \mathrm{~m}$ for each 90-day pathway are presented in Figure 9. The offshore pathway (left column) produces the bulk of PEPs in all seasons $(63-72 \%)$, peaking in summer and then dropping to the minimum in autumn. Patterns can be seen in the meridional depth distributions of the PEPs, which occupy the full extent of the entire target zone. There
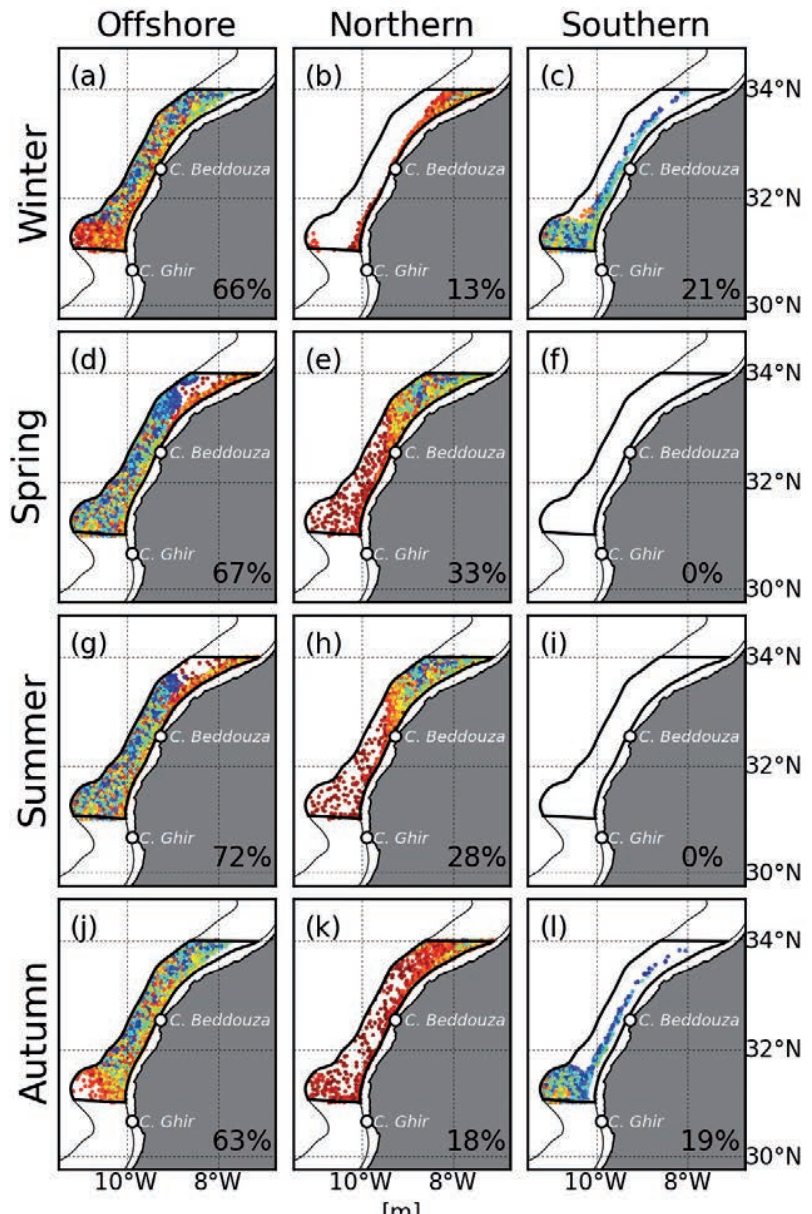

$[\mathrm{m}]$

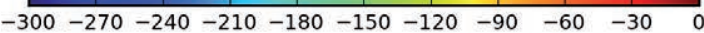

FIG. 9. - Distributions of seasonal release locations (runs 5-8; Table 1) within the target zone $(0-300 \mathrm{~m})$ for the offshore, northern and southern pathways identified in Figure 5. The relative percentages for each season are shown (from a sample of 6294 floats). Colours correspond to particle depth. The 100- and 2000-m isobaths are demarked by the thin black line. 

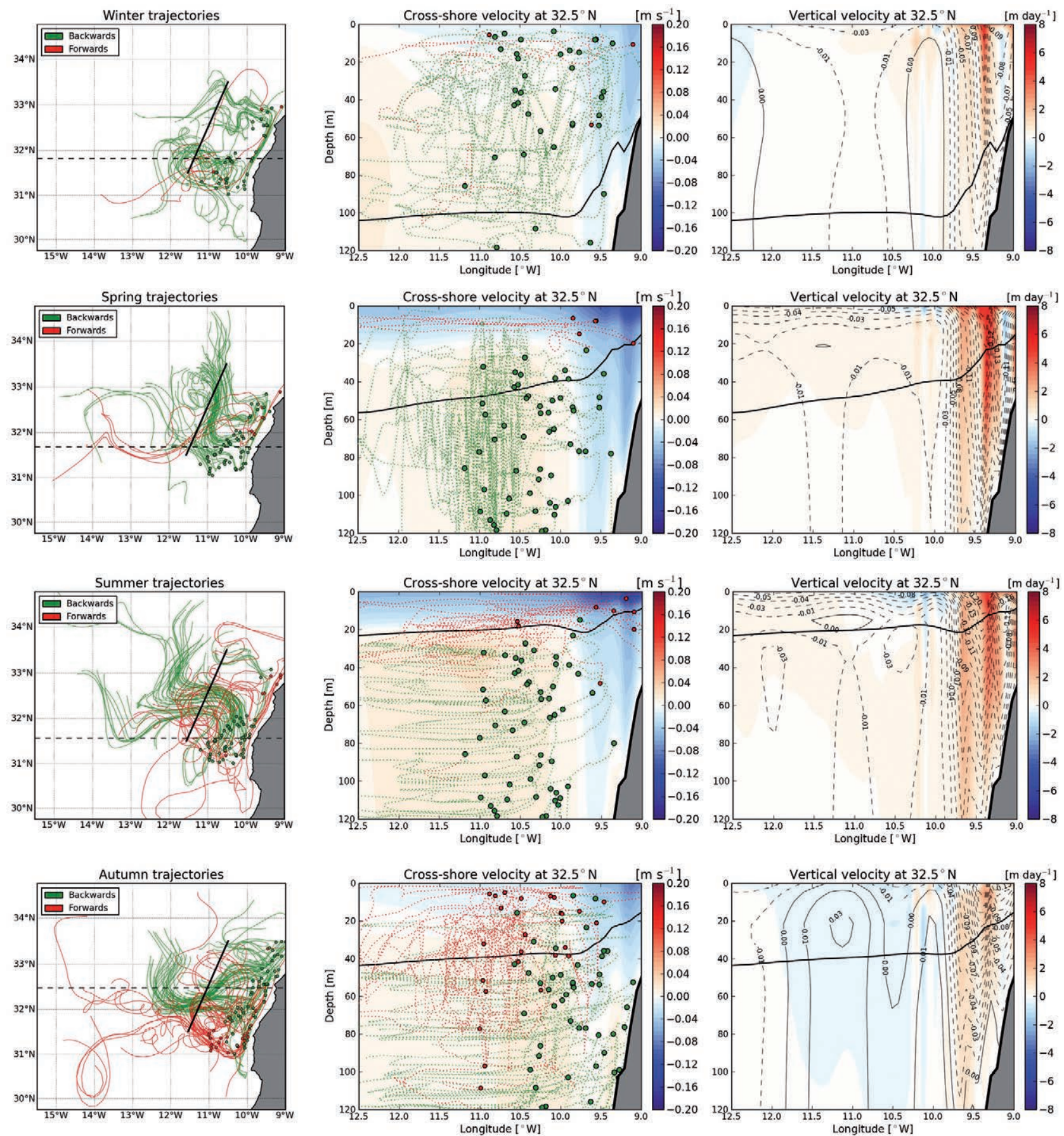

FIG. 10. - 90-day seasonal trajectories filtered at 0-120 m from backwards runs 5, 6, 7, 8 and forwards runs 13, 14, 15, 16 (Table 1). Left-hand column: From an initial random selection of 163 trajectories, only trajectories passing through the thick black line between $31.5^{\circ} \mathrm{N}$ and $33.5^{\circ} \mathrm{N}$ are plotted. Dashed lines mark the mean latitude of the backwards run arrivals (PEPs) within the target zone. Middle column: The selected trajectories are plotted as functions of longitude and depth. Also shown are filled colour contours of seasonal mean cross-shore velocity, and the mixed layer depth is marked in black. Right-hand column: Filled colour contours show the seasonal mean vertical velocity, while black line contours show alongshore velocity. The mixed layer depth is marked in black.

is a general trend for shallower (deeper) particles to be found inshore (offshore). This is most apparent in spring and summer, suggesting a well-developed Ekman circulation in response to the increased seasonal wind stress. Exceptions to the cross-shore pattern are visible in winter and autumn to the northwest of
Cape Ghir, where surface PEPs are prevalent all the way to the offshore boundary of the target area. The northern pathway (centre column) displays considerable seasonal variability; peak arrivals are in spring (33\%), whereas the percentages fall successively over the following seasons to a low of $13 \%$ in winter. 
The bulk of the PEPs are located close to the surface, especially those south of Cape Beddouza. Inshore particles near to the $100-\mathrm{m}$ isobath are likely to be transported southward by the CanUC (see Fig. 2b). Indeed, Pelegrí et al. (2005a) describe the trajectories of two surface drifters released in the Gulf of Cadiz in February 1988. The drifters, after an initial period of instability within the Gulf, were advected southwards, passing Cape Ghir in May 1988 and entering the LP during the summer. The southern pathway (right column) makes its PEP contributions in autumn and winter (19\% and $21 \%$, respectively), in clear association with the annual November reversal to poleward flow of the EBC (see Introduction and Figure 3d). The southern pathway PEPs are consistently located at $250 \mathrm{~m}$ (this is the mean depth of the poleward undercurrent), below those of the northern pathway which are at CanUC depths. North of about $31.5^{\circ} \mathrm{N}$, the southern pathway appears to form a concentrated stream, suggesting a predominantly along-slope path for the poleward undercurrent (see Figure 2b). In spring and summer there are no PEP contributions to the southern pathway.

Figure 10 shows seasonal 90-day backwards and forwards trajectories released within the target area at 0-120 m depth (left and middle columns); and meridional averages $\left(31.5-33.5^{\circ} \mathrm{N}\right)$ of cross-shore, vertical, and alongshore velocity (middle and right columns). The trajectories are filtered to show only particles that pass through an alongshore orientated transect between $31.5^{\circ} \mathrm{N}$ and $33.5^{\circ} \mathrm{N}$; this transect favours the offshore pathway and was selected in order to examine the seasonal variability of the cross-shore motions in the upwelling region. The backwards trajectories (left column, in green) follow rather well-defined pathways as they approach the target zone. The longest trajectories are in summer, and the shortest in winter. A measure of correspondence between the trajectories and the 0-300 $\mathrm{m}$ streamlines is apparent (cf. Fig. 3). In summer, south of $34^{\circ} \mathrm{N}$, the CanC is visible at $10-14^{\circ} \mathrm{W}$ transporting $\sim 3 \mathrm{~Sv}$; it is fed in the north by both northwesterly and northeasterly branching from the AzC. These branches can be seen in the trajectories, which converge at $33.5^{\circ} \mathrm{N}$ and then continue southward until $32.5^{\circ} \mathrm{N}$, where they turn onshore towards the target zone, influenced by a growing cyclonic anomaly off Cape Beddouza centred around $10^{\circ} \mathrm{W}, 33^{\circ} \mathrm{N}$ (Fig. 3c). Particle arrivals are concentrated towards the south; the mean PEP latitude in the target area is $31.6^{\circ} \mathrm{N}$ (marked by the horizontal black dashed line in Figure 10c). Similar correspondences can be seen during the following seasons, when the role of the Cape Beddouza cyclonic anomaly is especially evident in spring and autumn. In spring, particle arrivals are again concentrated towards the south of the target zone. In contrast, autumn particle arrivals are mostly found over the central and northern regions of the target zone; this is attributable to the reversal of the EBC. This cycle of particle arrivals, concentrated in the south in spring and summer, then rapidly shift- ing northwards in autumn, is punctuated in winter by a relatively low number of arrivals that are distributed over the full meridional extent of the target zone.

The vertical sections of velocity in Figure 10 complete the description of the simulated upwelling, and provide an illustrative link between the hydrodynamic solution and the simulated trajectories. In the middle column, offshore flow is present all year in the upper layers, with weak onshore flow below. Alongshore flow in the right column is generally southward, being particularly intense in the surface nearshore region in association with the CanUC. The offshore alongshore flow becomes weakly positive in autumn when the EBC briefly reverses. Convergence in the cross-shore flow below the simulated mixed layer occurs within about one degree of the coast, and signals the raising of the mixed layer depth with proximity to the shore. This inner region is also characterised by significant vertical velocities (mostly positive, hence upwelling), with maximum values of up to $8 \mathrm{~m} \mathrm{day}^{-1}$ in spring and summer (right column). In the summertime there is weak upwelling below the mixed layer which extends offshore, as far as about $12^{\circ} \mathrm{W}$, this being the cause of the summer offshore extension in the integrated normalized vertical velocity (Fig. 4d). The surface offshore transport is most intense in summer, when the mixed layer depth is only $\sim 20 \mathrm{~m}$. Also shown in Figure 10 (middle column) are vertical sections of the zonal positions of the previously plotted trajectories (left column). In summer and autumn the trajectories are dominated by horizontal motions, probably as a result of the high vertical stratification, whereas in winter and spring vertical motions are important.

Forwards trajectories are shown in red in Figure 10 (left and middle columns). The bulk of the summer and autumn trajectories proceed in the offshore direction within the surface layers, where many are strongly influenced by Ekman transport dynamics. The autumn CanUC cohort moves abruptly offshore at $31^{\circ} \mathrm{N}$, suggesting a reinforcement of the Cape Ghir filament (cf. Fig. 3d). The meridional filter selects insignificant numbers of forwards trajectories in winter and spring, indicating that most water parcels flow meridionally under the influence of the CanUC.

\section{CONCLUDING REMARKS}

This study represents a first step towards a quantitative understanding of the sources and pathways associated with the Canary Upwelling System (CUS) circulation. This knowledge is important as we work towards an understanding of the response of the coastal ocean to current and future climatic conditions. The deployment of observing systems, such as an array of current-meter moorings in the CUS in the region north of Cape Ghir, would provide a valuable means to gain insight into the CUS circulation. However, cost and logistical limitations make this unfeasible at present, so we must turn to numerical simulations. Furthermore, 
numerical simulations remain the only possible way to obtain a measure of the temporal and spatial distributions of vertical velocity fields in upwelling regions.

The simulations were forced using seasonal mean and interannual velocity outputs from a high-resolution ROMS configuration of the Canary Basin. The results presented here from the Roff Lagrangian particle-tracking model suggest that this approach is a promising avenue for further study of the CUS. However, it must be stressed that the Lagrangian results are highly dependent on the fidelity of the hydrodynamic (ROMS) solution. This solution has been elsewhere validated using observational data (Mason et al. 2011), but the ocean is severely undersampled below the surface, which is precisely the region we wish to study with Roff.

Before discussing our results, we comment on two potential problems with our numerical procedure. First, the omission of the effects of diffusion on the trajectories, which are directly forced by the ROMS velocity fields, may be a source of error. Diffusive effects should not significantly modify the mean parcel pathways, as we use large ensembles of floats which lead to representative Lagrangian pathways (Rivas and Samelson 2011). Second, the quantification of the ROMS vertical fluxes that force the Lagrangian model undoubtedly depends on a correct parameterisation of vertical mixing (in our case, KPP); obtaining error bars would require a careful study of the sensitivity of the results to vertical parameterization that goes beyond the objectives of the present study.

We see a strong correlation between the pathways of incoming trajectories (Figs. 7, 8 and 10) and the mean seasonal circulation of the CanC (defined by the streamfunction in Figure 3), which is mediated by perturbations to the flow by westward-propagating baroclinic Rossby waves generated near to the coast (Mason et al. 2011). Our solutions provide insight into the connecting pathways between the offshore and coastal ocean, showing details that are not resolvable from the seasonal streamfunction. Discrepancies between actual trajectories and streamlines are largely due to the mesoscale circulation. Other significant differences are possibly related to the different time scales of the interior and coastal oceans: while the large-scale deepocean circulation changes at time scales of the order of months the coastal ocean responds much faster as a result of the passage of intermittent atmospheric frontal systems (of the order of days or weeks).

Our analyses have addressed questions about the origins of the seasonal source waters within the CUS. The main finding is the contrast between year-long and season-long paths: year-long paths come predominantly from offshore all year round, their principal source being the Azores Current, while an important fraction of the northern season-long paths (from around $15 \%$ in winter to $40 \%$ in spring and summer) recirculate through the southern Gulf of Cadiz. Nevertheless, offshore pathways dominate at both annual and seasonal timescales; these pathways are regulated by seasonal variability of the CanC, which in turn is thought to be modulated by Rossby waves that emanate from the northwest African coast. Northern pathways remain significant all year, reinforcing the idea that during these seasons the CanUC remains attached to the continental slope (Machín et al. 2006b). These pathways are composed of offshore surface waters recirculating through the Gulf of Cadiz, in what constitutes the origin of the along-slope horizontal upwelling cell and the major path for the coastal recirculation of the Azores Current. Southern along-slope pathways originate at or south of the Canary Islands and are located below the surface mixed layer; they are important only in autumn and winter.

Finally, we have assessed the importance of actual upwelling, as measured by vertical velocities at the base of the surface mixed layer, compared with the wind-induced cross-shore Ekman transport. An important result is the existence of substantial temporal and spatial variability of these vertical velocities. The maximum annual mean values appear locked near to Cape Beddouza, therefore suggesting a topographic role in the three-dimensionality of the flow. The temporal variability has been examined in the $32-33^{\circ} \mathrm{N}$ region, sufficiently far from the Canary Islands to minimise their topographic effect. It is shown that maximum values do not occur during the intense summer northeasterly winds (probably because of the inhibiting effects of the well-stratified surface mixed layer) but rather in autumn, when wind remains intense and stratification has decreased, and during winter, probably because of the contribution from winter convection.

\section{ACKNOWLEDGMENTS}

This research was supported by the Spanish government through projects MOC2 (CTM200806438-C02-01) and TIC-MOC (CTM2011-28867).

\section{REFERENCES}

Arístegui J., Sangrà P., Hernández-León S., Cantón M., HernándezGuerra A., Kerling J.L. 1994. Island-induced eddies in the Canary Islands. Deep-Sea Res. 49: 1087-1101.

Arístegui J., Barton E.D., Álvarez-Salgado X.A., Santos A.M.P., Figueiras F.G., Kifani S., Hernández-León S., Mason E., Machú E., Demarcq H. 2009. Sub-regional ecosystem variability in the Canary Current upwelling. Prog. Oceanogr. 83: 33-48.

Bakun A., Field D.B., Redondo-Rodriguez A., Weeks S.J. 2010: Greenhouse gas, upwelling-favorable winds, and the future of coastal ocean upwelling ecosystems. Global Change Biol. 16: 1213-1228.

Barton E.D. 1989. The poleward undercurrent on the eastern boundary of the subtropical North Atlantic. In: Neshyba S.J., Mooers C.N.K., Smith R.L., Barber R.T. (eds.), Poleward Flows Along Eastern Ocean Boundaries, Coastal and Estuarine Studies, Vol. 34. Springer, pp. 82-95.

Barton E.D., Arístegui J., Tett P., Cantón M., Garcia-Braun J., Hernandez-Leon S., Nykjaer L., Almeida C., Almunia J., Ballesteros S., Basterretxea G., Escanez J., Garcia-Weill L., Hernandez-Guerra A., Lopez-Laatzen F., Molina R., Montero M.F., Navarro-Perez E., Rodriguez J.M., van Lenning K., Velez H., Wild K. 1998. The transition zone of the Canary Current upwelling region. Prog. Oceanogr. 41: 455-504. 
Benítez-Barrios V.M., Pelegrí J.L., Hernández-Guerra A., Lwiza K.M.M., Gomis D., Vélez-Belchi P., Hernández-León S. 2011. Three-dimensional circulation in the NW Africa coastal transition zone. Progr. Oceanogr. 91: 516-533.

Borges M.F., Santos A.M.P., Crato M., Mendes H., Mota B. 2003. Sardine regime shifts off Portugal: A time series analysis of catches and wind conditions. Sci. Mar. 67: 235-244.

Brochier T., Mason E., Moyano M., Berraho A., Colas F., Sangra P., Hernandez-Leon S.,Ettahiri O., Lett C. 2011. Ichthyoplankton transport from the African coast to the Canary Islands. J. Mar. Syst, 87: 109-122.

Candela J. 2001. Mediterranean water and global circulation. In Siedler G., Church J., Gould J. (eds.), Ocean Circulation and Climate. Academic Press, New York, pp. 419-429.

Capet X.J., Campos E.J., Paiva A.M. 2008. Submesoscale activity over the Argentinian shelf. Geophys. Res. Lett. 35: L15605.

Carr M.-E., Kearns E.J. 2003. Production regimes in four Eastern Boundary Current systems. Deep-Sea Res. 50: 3199-3221.

Carr S.D., Capet X.J., McWilliams J.C., Pennington J.T., Chavez F.P. 2008. The influence of diel vertical migration on zooplankton transport and recruitment in an upwelling region: estimates from a coupled behavioral-physical model. Fish. Oceanogr. 17: 1-15.

Durand M.-H., Cury P., Mendelssohn R., Roy C., Bakun A., Pauly D. 1998. Global Versus Local Changes in Upwelling Systems. ORSTOM, Paris.

Estrade P., Marchesiello P., Colin de Verdiére A., Roy C. 2008. Cross-shelf structure of coastal upwelling: A two-dimensional extension of Ekman's theory and a mechanism for inner shelf upwelling shut down. J. Mar. Res. 66: 589-616.

Fraile-Nuez E., Machín F., Vélez-Belchí P., López-Laatzen F., Borges R., Benítez-Barrios V., Hernández-Guerra A. 2010. Nine years of mass transport data in the eastern boundary of the North Atlantic Subtropical Gyre. J. Geophys. Res. 115: C09009.

Gómez-Gesteira M., de Castro N., Álvarez I., Lorenzo M.N., Gesteira J.L.G., Crespo A.J.C. 2008. Spatio-temporal Upwelling Trends along the Canary Upwelling System (1967-2006). Ann. New York Acad. Sci. 1146: 320-337.

Hagen E. 2001. Northwest Africa upwelling scenario. Oceanol. Acta 24: 113-128.

Hunter P., Macnab R. 2003. The GEBCO Digital Atlas published by the British Oceanographic Data Centre on behalf of IOC and IHO. North Atlantic region.

Laiz I., Sangrà P., Pelegrí J.L., Marrero-Díaz A. 2001. Sensitivity of an idealized subtropical gyre to the eastern boundary conditions. Sci. Mar. 65(S1): 187-194.

Lamas L., Peliz A., Ambar I., Aguiar A.B., Maximenko N., TelesMachado A. 2010. Evidence of time-mean cyclonic cell southwest of the Iberian Peninsula: The Mediterranean Outflowdriven $\beta$-plume? Geophys. Res. Lett. 37: L12606.

Large W.G., McWilliams J.C., Doney S.C. 1994. Oceanic vertical mixing: A review and a model with a vertical K-profile boundary layer parameterization. Rev. Geophys. 32: 363-403.

Lathuiliére C., Echevin V., Lévy M. 2008. Seasonal and intraseasonal surface chlorophyll-a variability along the northwest African coast. J. Geophys. Res. 113: C05007.

Lozier S.M., Owens S.B., Curry R.G. 1995. The climatology of the North Atlantic. Prog. Oceanogr. 36: 1-44.

Machín F., Hernández-Guerra A., Pelegrí J.L. 2006a. Mass fluxes in the Canary Basin. Prog. Oceanogr. 70: 416-447.

Machín F., Pelegrí J.L. 2009. Northward Penetration of Antarctic Intermediate Water off Northwest Africa. J. Phys. Oceanogr. 39: $512-535$.

Machín F., Pelegrí J.L., Marrero-Díaz A., Laiz I., Ratsimandresy A.W. 2006b. Near-surface circulation in the southern Gulf of Cádiz. Deep-Sea Res. 53: 1161-1181.

Marcello J., Hernández-Guerra A, Eugenio F., Fonte A. 2011. Seasonal and temporal study of the northwest African upwelling system. Int. J. Rem. Sens. 32: 1843-1859.

Marchesiello P., McWilliams J.C., Shchepetkin A.F. 2003. Equilibrium structure and dynamics of the California Current System. J. Phys. Oceanogr. 33: 753-783.

Mason E. 2009. High-resolution modelling of the Canary Basin oceanic circulation. Ph.D. thesis, Universidad de Las Palmas de Gran Canaria, URL http://hdl.handle.net/10553/5004, 235pp.

Mason E., Colas F., Molemaker J., Shchepetkin A.F., Troupin C., McWilliams J.C., Sangrà P. 2011. Seasonal variability of the Canary Current: a numerical study. J. Geophys. Res. 116: C06001.
Mason E., Molemaker J., Colas F., Shchepetkin A.F., McWilliams J.C., Sangrà P. 2010. Procedures for offline grid nesting in regional ocean models. Ocean Model. 35: 1-15.

Mauritzen C., Morel Y., Paillet J. 2001. On the influence of Mediterranean Water on the Central Waters of the North Atlantic Ocean. Deep-Sea Res. 48: 347-381.

Montes I., Colas F., Capet X.J., Schneider W. 2010. On the pathways of the Equatorial Subsurface Currents in the Eastern Equatorial Pacific and their contributions to the Peru-Chile Undercurrent. J. Geophys. Res. 115: C09003.

Nykjær L.,Van Camp L. 1994. Seasonal and interannual variability of coastal upwelling along northwest Africa and Portugal from 1981 to 1991. J. Geophys. Res. 99: 14197-14207.

Ochoa J., Bray N.A. 1991. Water mass exchange in the Gulf of Cadiz. Deep-Sea Res. 38: S465-S503.

Pascual A., Faugère Y., Larnicol G., Le Traon P.-Y. 2006. Improved description of the ocean mesoscale variability by combining four satellite altimeters. Geophys. Res. Lett. 33: L02611.

Pelegrí, J. L., A. Marrero-Díaz, and A. W. Ratsimandresy, 2006: Nutrient irrigation of the North Atlantic. Prog. Oceanogr., 70 (2-4): 366-406.

Pelegrí J.L., Arístegui J., Cana L., González M., Hernández-Guerra A., Hernández-León S., Marrero-Díaz A., Montero M.F., Sangrá P., Santana-Casiano M. 2005. Coupling between the open ocean and the coastal upwelling region off Northwest Africa: Water recirculation and offshore pumping of organic matter. $J$. Mar. Syst. 54: 3-37.

Pelegrí J.L., Marrero A., Ratsimandresy A.W., Antoranz A., Cisneros J., Gordo C., Grisolía D., Hernández-Guerra A., Láiz I., Martínez A., Parrilla G., Pérez-Rodríguez P., Rodríguez-Santana A., Sangrá P. 2005. Hydrographic cruises off northwest Africa: The Canary Current and the Cape Ghir region. J. Mar. Syst. 54: 39-63.

Peliz A.J., Dubert J., Marchesiello P., Teles-Machado A. 2007. Circulation in the Gulf of Cadiz: Part I Model and mean flow structure. J. Geophys. Res. 112: C11015.

Peliz Á.J., Dubert J., Santos A.M.P., Oliveira P.B., Le Cann B. 2005. Winter upper ocean circulation in the Western Iberian Basin-Fronts, Eddies and Poleward Flows: an overview. DeepSea Res. 52: 621-646.

Penven P., Echevin V., Pasapera J., Colas F., Tam J. 2005. Average circulation, seasonal cycle, and mesoscale dynamics of the Peru Current System: A modeling approach. J. Geophys. Res. 110: C10021.

Piedeleu M., Sangrà P., Sánchez-Vidal A., Fabrés J., Gordo C., Calafat A. 2009. An observational study of oceanic eddy generation mechanisms by tall deep-water islands (Gran Canaria). Geophys. Res. Lett. 36: L14605.

Ratsimandresy A.W., Pelegrí J.L., Marrero-Díaz A., HernándezGuerra A., Antoranz A., Martínez A. 2001. Seasonal variability of the upper warmwatersphere in the Canary Basin. Sci. Mar. 65(S1): 251-258.

Rio M.-H., Hernández F. 2004. A mean dynamic topography computed over the world ocean from altimetry, in situ measurements and a geoid model. J. Geophys. Res. 109: C12032.

Risien C.M., Chelton D.B. 2008. A Global Climatology of Surface Wind and Wind Stress Fields from Eight Years of QuikSCAT Scatterometer Data. J. Phys. Oceanogr. 38: 2379-2413.

Rivas D., Samelson R.M. 2011. A Numerical Modeling Study of the Upwelling Source Waters along the Oregon Coast during 2005. J. Phys. Oceanogr. $41: 88-112$.

Roy C., Cury P., Fontana A., Belvèze H. 1989. Stratégies spatio-temporelles de la reproduction des clupéidés des zones d'upwelling d'Afrique de l'Ouest. Aquat. Living Resour. 2: 21-29.

Rykaczewski R.R., Checkley D.M.Jr. 2008. Influence of ocean winds on the pelagic ecosystem in upwelling regions. Proc. Natl. Acad. Sci. 105: 1965-1970.

Sangrà P., Pascual A., Rodríguez-Santana A., Machín F., Mason E., McWilliams J.C., Pelegrí J.L., Dong C., Rubio A., Arístegui J., Marrero-Díaz A., Hernández-Guerra A., Martínez-Marrero A., Auladell M. 2009. The Canary Eddy Corridor: a major pathway for long-lived eddies in the North Atlantic. Deep-Sea Res. 56: 2100-2114.

Santos A.M.P., Kazmin A.S., Peliz A.J. 2005. Decadal changes in the Canary upwelling system as revealed by satellite observations: Their impact on productivity. J. Mar. Res. 63: 359-379.

Santos A.M.P., Peliz A.J., Dubert J., Oliveira P.B., Ré P. 2004. Im- 
pact of a winter upwelling event on the distribution and transport of sardine (Sardina pilchardus) eggs and larvae off western Iberia: a retention mechanism. Cont. Shelf Res. 24: 149-165.

Shchepetkin, A. F. and J. C. McWilliams, 2005: The Regional Oceanic Modeling System (ROMS): a split-explicit, free-surface, topography-following-coordinate oceanic model. Ocean Model. 9(4): 347-404.

Shchepetkin A.F., McWilliams J.C. 2009. Correction and Commentary for "Ocean Forecasting in Terrain-Following Coordinates: Formulation and Skill Assessment of the Regional Ocean Modeling System" by Haidvogel et al. J. Comp. Phys. 227, pp. 3595-3624. J. Comput. Phys. 228: 8985-9000.

Siedler G., Finke M. 1993. Long-Period Transport Changes in the Eastern North Atlantic and Their Simulation by Propagating Waves. J. Geophys. Res. 98: 2393-2406.

Speth P., Detlefsen H. 1982. Meteorological influences on upwelling off Northwest Africa. Rapp. p.-v. Reun. ICES, 180, 29-34.

Stommel H. 1979. Determination of water mass properties of water pumped down from the Ekman layer to the geostrophic flow below. Proc. Natl. Acad. Sci. 76: 3051-3055.
Stramma L. 1984. Geostrophic transport in the warm water sphere of the eastern subtropical North Atlantic. J. Mar. Res. 42: 537-558.

Troupin C., Machín F., Ouberdous M., Sirjacobs D., Barth A., Beckers J.-M. 2010. High-resolution climatology of the northeast Atlantic using Data-Interpolating Variational Analysis (DIVA). J. Geophys. Res. 115: C08005.

Van Camp L., Nykjaer L., Mittelstaedt E., Schlittenhardt P. 1991. Upwelling and boundary circulation off northwest Africa as depicted by infrared and visible satellite observations. Prog. Oceanogr. 26: 357-402.

Wooster W.S., Bakun A., McLain D.R. 1976. The seasonal upwelling cycle along the eastern boundary of the North Atlantic. J. Mar. Res. 34: 131-140.

Worley S.J., Woodruff S.D., Reynolds R.W., Lubker S.J., Lott N. 2005. ICOADS release 2.1 data and products. Int. J. Climatol. 25: 823-842.

Received March 31, 2011. Accepted October 5, 2011.

Published online August 3, 2012. 